\title{
Gender Bias and Credit Access
}

\author{
Steven Ongena \\ University of Zurich, SFI and CEPR
}

\author{
Alexander Popov* \\ European Central Bank
}

\begin{abstract}
This paper studies the causal effect of gender bias on access to bank credit. We extract an exogenous measure of gender bias from survey responses by descendants of US immigrants on questions about the role of women in society. We then use data on 6,000 small business firms from 17 countries and find that in countries with higher gender bias, female-owned firms are more frequently discouraged from applying for bank credit and more likely to rely on informal finance. At the same time, loan rejection rates and terms on granted loans do not vary between male and female firm owners. These results are not driven by credit risk differences between female- and male-owned firms or by any idiosyncrasies in the set of countries in our sample. Overall, the evidence suggests that in high-gender-bias countries, female entrepreneurs are more likely to opt out of the loan application process, even though banks do not appear to actively discriminate against females that apply for credit.
\end{abstract}

JEL classification: G21, J16, N32, Z13.

Keywords: Cultural bias; Gender-based discrimination; Bank credit; Female-owned firms.

\footnotetext{
* Corresponding author. Address: Kaiserstrasse 29, D 60311 Frankfurt am Main, Germany. Telephone: +49 69 13448428. Email: alexander.popov@ecb.int. We would like to thank Thorsten Beck, Allen Berger (FIRS discussant), Andre Guttler, Byeongju Jeong, Stepan Jurajda, Charlotte Ostergaard, and seminar participants at CERGE and at the 2013 FIRS (Dubrovnik) for useful discussions. The paper was previously circulated under the title "'Take care of home and family, honey, and let me take care of the money": Gender bias and credit market barriers for female entrepreneurs." The opinions expressed herein are those of the authors and do not necessarily reflect those of the ECB or the Eurosystem.
} 
A woman cannot be herself in the society of the present day, which is an exclusively masculine society, with laws framed by men and with a judicial system that judges feminine conduct from a masculine point of view. Henrik Ibsen, Ibsen's Workshop, 1912

\section{Introduction}

Economic research has focused intensely in recent years on the link between culturewhich Guiso, Sapienza, and Zingales (2006) define as the customary beliefs and values that are transmitted fairly unchanged from generation to generation-and economic outcomes. Scholars have provided strong evidence that various beliefs and preferences, rooted in the cultural experience of economic agents, are related to a wide array of economic phenomena, ranging from growth (Knack and Keefer, 1997) and financial development (Guiso, Sapienza, and Zingales, 2004), to trade (Guiso, Sapienza, and Zingales, 2009) and regulation (Aghion, Algan, Cahuc, and Shleifer, 2010).

Having established a robust correlation, the research effort has turned to identifying the causal impact of culture on economic outcomes. Doing so requires taking two crucial steps. First, one needs to show that a narrow subset of the entire range of cultural beliefs and preferences has a directly measurable impact on a specific economic phenomenon. Second, one needs to show that not only the contemporaneous component of these beliefs and preferences, but also their predetermined component, has an impact on the economic outcome in case.

This paper aims to take both steps concurrently by investigating the impact of a welldefined cultural belief-i.e., the belief that women are inferior to men, or the gender bias-on a well-defined economic outcome, i.e., credit access. Specifically, we study whether, in high- 
gender-bias countries and relative to male-owned counterparts, females-owned firms: (1) Are more often denied bank credit; (2) are more often discouraged from applying for bank credit; (3) rely less on bank credit and more on alternative sources of finance, such as trade credit, in the financing of the operations of their firm; and (4) are offered inferior terms on granted loans.

Establishing a causal link from gender bias to credit market outcomes is at the heart of our paper. To extract the predetermined component of the gender bias across our sample countries, we borrow the empirical strategy from Algan and Cahuc (2010) who employ information on cultural attitudes of US-born descendants of European immigrants to extract measures of inherited trust and investigate its effect on economic growth. We focus on answers provided by U.S. descendants of European immigrants to survey questions about the proper place of women in society. For instance, we compare Americans of German, Polish, or Russian origin whose ancestors immigrated to the US in 1960. Since it is well established that social capital is transmitted from parents to children (Putnam, 2000; Guiso, Sapienza, and Zingales, 2006), the degree of the gender bias of a person born in the U.S. that has parents that were born in Russia is a good proxy for the degree of gender bias of his parents, and by extension a good proxy for the predetermined component of gender bias in contemporaneous Russia.

This measurement strategy allows us to isolate the inherited component of the gender bias for 17 European countries. Our measure of inherited gender bias is clearly superior-in a causal sense-to similar measures that are commonly extracted from contemporaneous surveys of cultural attitudes in these countries, such as the World Values Survey, that may be directly influenced by the current experiences of the surveyees including those in credit markets.

Next, we match our country-specific proxy for gender bias to information on the credit market experience by 5,905 firm owners - 4,193 males and 1,712 females - in these countries, and test whether variation in inherited cultural biases is mapped into variation in credit access 
and in the terms on loans and credit lines granted by banks. We focus on small individually- or family-owned firms to make sure that if one of the owners of the firm is female, she is materially influential in the firm's decisions.

We find that cross-country differences in gender bias explain a substantial proportion of the variation in credit access by female firm owners, but not in loan rejection rates or in the loan terms of the ultimately successful loan applications. In particular, in countries with a higher inherited gender bias and relative to male entrepreneurs, female entrepreneurs more often do not apply for a loan because they believe they will not get one, and finance a higher share of their firm's operating expenses with trade credit rather than with bank credit. However, once the firm applies for a loan or a line of credit, we find - in most specificationsno statistical differences between male- and female-owned firms in the probability of application denial. We also find no differences in the terms on granted loans, such as interest rates, collateral requirements, and the negotiation time involved.

The evidence thus suggests that culture matters for economic outcomes. In particular, the data point to a self-selection of female entrepreneurs out of the loan application process in high-gender-bias countries. Importantly, this self-selection is largely driven by the female firm owner's belief that her credit application will be denied. Our results are observed even when country and industry fixed effects (which capture important time-invariant variation within the high versus low gender-bias group), a wide range of firm-specific characteristics, and a nearly exhaustive set of characteristics capturing the national business environment are included. At the same time, female firm owners are not subject to higher loan denial rates or a higher price of credit in high-gender-bias countries, relative to male owners. This may imply no taste-based discrimination by banks if male-owned and female-owned applicant firms are of similar quality, or it may point to taste-based discrimination if most male-owned firms apply for credit, but only the best female-owned ones do. 
A related concern is that higher gender bias can over time trigger changes in the skill composition of the labor force through the selection of workers into education or employment, or through migration, for instance (Mulligan and Rubinstein, 2008). One potential implication is that in countries with high gender bias, female firm owners' set of skills required to run a firm could be inferior. However, we find that there is no statistical difference in firm growth between female-owned and male-owned firms. Even stronger than that, we show that in highgender-bias countries, there is no statistical difference in growth rates between constrained female-owned firms and unconstrained male-owned firms. This lack of difference combined with our findings that female entrepreneurs are more likely to be discouraged from applying for a loan, especially in high-gender-bias countries, suggests the possibility of taste-based discrimination, though this time at the loan approval stage. Indeed, if only the most capable and competitive females start a business and therefore can survive to the loan application stage, the average female entrepreneur would be more skilled than the average male entrepreneur. If so, our estimates of equal loan conditions would then be consistent with the effects of taste-based discrimination rather than with the rationing of potentially inferior projects by banks in countries with a pronounced gender bias, though admittedly unobservables may play a well-known confounding role in this setting. ${ }^{1}$

Overall, our evidence is related to the analysis in Cavalluzzo, Cavalluzzo, and Wolken (2002), Muravyev, Schäfer, and Talavera (2009), and Hertz (2011) who find that female-owned firms are less likely to apply for and/or to obtain bank credit than male-owned firms, both in the US and in an international context. However, to our knowledge, our paper is the first to

\footnotetext{
${ }^{1}$ Indeed sales growth may be affected by latent unobservables directly and then potentially negatively (i.e., females may have worse unobservables) and indirectly through selection and then potentially positively (i.e., only the best females participate). Hence in our sales growth assessment, the incentives for statistical discrimination and the practice of taste based discrimination could consequently become confounded. For a development of this discussion related to race discrimination in mortgage lending see, e.g., Berkovec, Canner, Gabriel, and Hannan (1994, 1996, 1998) on the one hand, and, e.g., Ross (1996, 1997), Ross, Galster, and Yinger (1996), and Ross and Yinger (2002) on the other hand.
} 
make the empirical link between gender, a specific economic outcome (credit access), and the gender bias.

We are clearly not the first to analyze the impact of cultural beliefs and preferences on economic outcomes. ${ }^{2}$ Our contribution to this extant literature is that we uncover a specific mechanism through which culture affects economic growth, namely through the gender bias and the differential access to credit. To make this contribution we borrow the identification strategy introduced by Algan and Cahuc (2010). They use the cultural attitudes of U.S.-born descendants of non-U.S. born ancestors to extract another predetermined component of culture, i.e., trust, in the ancestral countries and in this way made an important contribution to this literature.

The second related strand of the literature analyzes the relation between well-defined characteristics of the credit market and various social outcomes. Garmaise and Moskowitz (2006) for example show that bank mergers result in substantially higher property crime rates, because lower access to finance depresses local economic growth and raises the relative benefit of illegal activity. Beck, Levine, and Levkov (2010) show that bank deregulation is associated with a tighter distribution of income, an outcome that is not due to better access to credit for poorer households, but to an increase in the relative demand for low-skilled workers by business firms. While we do not explore the link between the structure of the credit market

\footnotetext{
2 Putnam, Leonardi, and Nanneti (1993) for example show that social capital is a good predictor of government performance across Italian regions. Guiso, Sapienza, and Zingales show that trust in society affects phenomena such as entrepreneurship (2006) and trade (2009). Algan and Cahuc (2009) and Aghion, Algan, and Cahuc (2011) analyze the relationship between trust and institutions and find that, in general, countries whose citizens trust each other less tend to put in place more restrictive institutions. Aghion, Algan, Cahuc, and Shleifer (2010) explain this result by arguing that distrust increases the public demand for government intervention whereas regulation in itself discourages the formation of trust. Tabellini (2008) analyzes the role of culture on the per-capita-income of European regions by using institutional history and literacy rates as an instrument for contemporaneous trust. Finally, Barr and Serra (2010) find that social norms in the home country are related to immigrants' tolerance for corruption.
} 
and economic outcomes, our work is naturally related to these studies in that we study how gender bias is transmitted into entrepreneurship through the channel of access to bank credit.

Our paper also relates to the literature on taste-based discrimination pioneered by Becker (1957). This literature has focused mainly on the labor market consequences of various physical attributes. ${ }^{3}$ Various authors have also looked into the effect of discrimination-as well as of its interaction with various market developments - on the white-black wage gap (Neal and Johnson, 1996; Rodgers and Sprigs, 1996; Bertrand and Mullainathan, 2004; Carneiro, Heckman, and Masterov, 2005; Charles and Guryan, 2008; Levine and Rubinstein, 2011). And, in a recent contribution, Castilo, Petrie, Torero, and Vesterlund (2013) find that difference between males and females in prices and rejection rates in a highly competitive taxi market with experienced traders is due to statistical, not to taste-based discrimination.

Conceptually similar to our study is the research on the effect of discrimination on the male-female wage gap (Bayard, Hellerstein, Neumark, and Troske, 2003), and on female market participation (Goldin and Rouse, 2000). This research in general confirms the existence of a sizeable earnings gender gap. For example, controlling for education, experience, personal characteristics, city and region, occupation, industry, government employment, and part-time status, Altonji and Blank (1999) find that only about 27 percent of the gender wage gap is explained by differences in observable characteristics. We argue that the difference in income between females and males can be related to cultural beliefs, with access to credit being one channel through which the gender bias can depress the earnings of women in society. To our knowledge, ours is the first paper to test for a direct link between the predetermined cultural component of gender discrimination and a well-defined economic outcome.

\footnotetext{
${ }^{3}$ For example, Hammermesh and Biddle (1994) and Mobius and Rosenblat (2006) find that physical beauty has a positive effect on earnings, while Cawley (2004) finds that obesity lowers the wages of white females. Persico, Postlewaite, and Silverman (2004) and Case and Paxson (2008) establish a robust effect of height on earnings, the latter through the channel of higher cognitive abilities. Johnston (2010) finds a substantial female wage premium from being blonde.
} 
Most related to our paper is the empirical research on gender and credit market outcomes. Using US data on small businesses, Asiedu, Freeman, and Nti-Addae (2012) find that while race is a significant predictor of both access to credit and the cost of credit (see also Bayer, Ferreira, and Ross, 2014), gender is not. Similarly, Asiedu, Kalonda-Kanyama, Ndikumana, and Nti-Addae (2013) show that there is no gender gap in most developing regions, except for sub-Saharan Africa where female-owned firms are found more likely to be financially constrained than male-owned firms. By documenting regional variation in the gender gap they provide further motivation for our analysis. Belluci, Borisov, and Zazzaro (2010) find that female firm owners in Italy face tighter credit constraints when dealing with one individual bank, even though they do not pay higher interest rates. Using the Italian Credit Registry, however, Alesina, Lotti, and Mistrulli (2013) find that after controlling for entrepreneurial risk, female borrowers do pay higher rates, especially when their guarantor is a female, too. Using a large crosscountry sample, Muravyev, Schäfer, and Talavera (2012) find that female firm owners are more likely to be denied bank credit and that they tend to pay higher rates on bank loans, while for a number of Sub-Saharan countries Aterido, Beck, and lacovone (2013) in contrast find no evidence of such gender discrimination. The first three papers use data from one country only and so unlike ours are unable to relate access to credit to the variation in cultural biases across countries. Relative to the latter two papers, we are not only able to link gender to credit outcomes in an international context, but also to investigate the effect of gender bias on that link.

The rest of the paper is organized as follows. Section 2 presents the data. Section 3 discusses our identification strategy. Our estimates of the effect of inherited cultural biases on credit market outcomes are presented in Section 4. Section 5 concludes.

\section{Data}

In this section, we discuss the various data sources used in this paper. 


\subsection{General Social Survey}

Our measure of the inherited gender bias is constructed using data on U.S. born descendants of non-U.S. born forebears. The information itself is provided by the General Social Survey database (GSS). The database covers the period 1972-2010. The data contains a range of demographic characteristics, such as age, gender, religion, marital status, education, and employment status of the respondents. Importantly for our purposes, it provides information on the birthplace and the country of origin of the respondents' forebears since 1977 . The respective GSS variable "ETHNIC" is defined as the answer to the question: "From what countries or part of the world did your ancestors come?" The countries of origin cover almost all European countries, alongside Canada, Mexico, India, and Africa (an aggregate category). We use information on U.S. citizens whose ancestors came from abroad, regardless of when they arrived in the U.S.

Our proxy for gender bias is derived from the variable "FEFAM" which is defined by the answer to following question: "It is much better for everyone involved if the man is the achiever outside the home and the woman takes care of the home and family." The answers are given on a scale from 1 to 4 . From these answers, we construct a variable for inherited gender bias which we denote as "Traditional gender roles". The variable is equal to 1 if the respondent answered "Strongly agree" or "Agree", and equal to 0 if the respondent answered "Disagree" or "Strongly disagree". There are a total of 20,992 responses in the GSS, of which 8,715 (41.5 percent) responded "Strongly agree" or "Agree", and 12,277 (58.5 percent) responded "Disagree" or "Strongly disagree". ${ }^{4} 6,472$ of those respondents come from 17 countries that overlap with the countries in our firm-level dataset which we describe next.

\footnotetext{
${ }^{4}$ Algan and Cahuc (2010) use an identical strategy to extract the predetermined component of trust from GSS answers on the question whether people in general can be trusted.
} 


\subsection{BEEPS}

Our firm-level data come from the 2004/2005 wave of the Business Environment and Enterprise Performance Survey (BEEPS), administered jointly by the World Bank and the European Bank for Reconstruction and Development (EBRD). We exclude data from other waves of this survey as they do not provide comparable information on credit access. The 2004 and 2005 BEEPS surveyed 9,655 firms from 27 countries in Eastern Europe and central Asia, and 4,453 firms from 5 Western European countries, respectively. We narrow this sample down to 17 countries for which we also have GSS data. ${ }^{5}$ In addition to that, we exclude all firms that are not sole proprietorships. This allows us to focus on small individually- or family-owned firms. In this way, we make sure that if one of the owners of the firm is female, she has actual influence in the firm's decisions. The number of firms that report all the information we require for this study ranges from 141 in Bosnia, Croatia, and Lithuania, to 763 in Poland. ${ }^{6}$

\subsubsection{Credit access}

To measure credit access by the firm we employ four different measures. We employ the self-reported Share working capital financed with bank credit and the Share working capital financed with trade credit as two direct measures of "past" access to credit. The survey questionnaire also includes three questions about firm financing which allow us to further describe firms' current access to credit. Firms are first asked if they have a loan or not. Those

\footnotetext{
${ }^{5}$ Unfortunately, due to the geographic scope of the survey, we are missing information from many European countries, such as the Scandinavian ones, that were pioneers in women's rights. We address this issue in a robustness test described in Section 4.B.

${ }^{6}$ The survey aimed to achieve representativeness in terms of the size of firms it surveyed: Roughly two thirds of the firms surveyed are "small", i.e., they have less than 20 workers. By design the survey only covers established firms, i.e., firms which have been in business for at least three years. This implies that our sample does not allow us to examine credit access for very young or start-up firms. Moreover, our results are subject to sample selection, in the sense that we only observe firms which had sufficient internal or external funds to survive for at least three years.
} 
firms without a loan are then asked whether they (a) did not apply for a loan or (b) applied for a loan, but the application was turned down or (c) have a loan application pending. ${ }^{7}$

Those firms that did not apply for a loan are then asked to list the main reasons why they did not do so. To this question there are multiple possible answers: (a) The firm does not need a loan, (b) application procedures are too burdensome, (c) collateral requirements are too strict, (d) interest rates are too high, (e) informal payments are necessary, or (f) the firm did not think their application would be approved. From the above questions we establish our two indicators of current credit access. The variable Firm discouraged from applying for a loan is a dummy variable which equals 1 for those firms which did not apply for a loan, listing (b), (c), (d), (e), or (f) as a potential reason. For all firms which did apply for a loan, or did not apply because of reason (a), the variable equals 0 . The variable Loan application rejected is a dummy variable which equals 1 for those firms which applied for a loan but their application was turned down, and equals 0 for those firms which applied for a loan and have a loan. Firms with pending applications (i.e., less than 1 percent) are treated as missing.

Table 1 presents summary statistics for our indicators of past and current credit access by country. The availability of data on discouraged firms is one of the main strengths of the BEEPS, allowing us to separate firms that did not apply for a loan because they do not need one from those that did not apply although they need one. As the table indicates, on average 23 percent of firms that need a loan are discouraged from applying, while only 5 percent of applicant firms are denied credit. Prior research has suggested that discouragement may signal an actual rejection if firms decide not to file an application after an informal conversation with the loan officer (see Duca and Rosenthal, 1993).

7 Despite the care by the surveyors to solicit the correct answers, it is not entirely impossible that males underreport past loan rejection or application discouragement more than females. Yet it seems rather unlikely to us that the (mis-)reporting of the shares of working capital would be gender-specific. 
Alongside variables describing various aspects of credit availability, we make use of a number of variables that describe the terms of granted bank loans. Firms with outstanding bank credit provide many details on their most recent loan. In particular, firms in BEEPS are asked about the loan rate, the maturity, the currency denomination, the collateral requirements, and the time it took to negotiate the last bank loan. Table 2 provides the sample summary statistics by country for the most relevant loan characteristics.

\subsubsection{Firm and country characteristics}

Recent empirical research by Brown, Jappelli, and Pagano (2009), Brown, Ongena, and Yeşin (2009), Brown, Ongena, Yeşin, and Popov (2011), Popov and Udell (2012), and Ongena, Popov, and Udell (2013) using the BEEPS data, and by Chakravarty and Xiang (2013) using the similar Investment Climate Survey data, has shown that firm size, ownership, activity, product market competition, accounting standards, bank use and internal financing, and obstacles to doing business affect credit access and credit terms.

Following the above literature we relate our indicators of credit access to firm-level indicators of firm size (Small firm, Medium firm, and Large firm), privatization history (Originally private), export activities (Exporter), the number of local product market competitors of the firm (Competition), access to government subsidies (Subsidized), and accounting standards (Audited). We further feature an indicator of the sector in which the firm operates (by SIC 1digit). Crucially, we incorporate information on the firm owner's gender (Female). While we do not have data on tangible assets to proxy for the ability of the firm to pledge collateral, the variables capturing firm size and industry of operation alleviate this problem to a large degree.

Furthermore, as in Pistor, Raiser, and Gelfer (2000), among others, we pay attention to how access to credit may be determined by market and institutional characteristics. In particular, we relate access to credit and loan terms to foreign ownership in the banking sector, to credit information sharing, and creditors' rights, as well as to various macroeconomic and financial developments. 
The definitions of all firm-level and country-level variables are provided in the Appendix. Summary statistics are presented in Appendix Table 1 (firm-level) and Appendix Table 2 (country-level).

\section{Identification strategy}

In this section, we discuss the construction of our measure of country-specific inherited gender bias, as well as the identification strategy.

\subsection{Inherited gender bias}

The construction of the country-specific measure of gender bias is based on the GSS. To simplify things, we do not focus on one particular generation, but take the answers of all respondents in the survey, regardless of what generation immigrants they are. Thus, inherited trust in 2005 corresponds to the trust inherited by U.S.-born children of European immigrants, born at any point after $1910 .^{8}$

The first two columns of Table 3 report marginal probit estimates of the gender bias for the full sample. ${ }^{9}$ The descendants of immigrants from all other countries are used as the reference group. ${ }^{10}$ The regression includes country-of-ancestry dummies, whose estimated coefficients are then used as the country-specific proxies for the gender bias. In addition to those, the regression controls for a host of individual-specific characteristics: Age, age squared,

\footnotetext{
${ }^{8}$ Paulson and Osili (2008) show that the ancestral beliefs of U.S. immigrants decline over time, suggesting that gender bias may be more pronounced for U.S. citizens who immigrated to the U.S. more recently. We perform tests using the latest wave of immigrants only, and our results are robust to this alternative measurement of the inherited gender bias.

${ }^{9}$ The OLS regression yields similar results.

${ }^{10} \mathrm{An}$ identical ranking of countries in terms of gender bias is obtained when we run the test on the 17 countries in the BEEPS data only, using Polish-Americans as a reference group.
} 
education, gender, religion, employment status, and income. The total number of observations for which data is available on all relevant variables is 21,073 .

The results imply that the gender bias increases with age and decreases with education. Males have a higher gender bias than females. All religious groups have a higher gender bias than atheists (the reference group), with the exception of Jewish respondents. Employed, unemployed, and retired persons have a lower gender bias relative to the control group (which is comprised of inactive persons). Finally, respondents with a higher income have a significantly lower gender bias.

Turning to the countries in our sample, the lowest gender bias in our sample-all else equal - is exhibited by the descendant of immigrants from Ireland, who are 4.8 percentage points less likely to agree that: "It is better if the man pursues a professional career and the woman takes care of the house and family" than the descendants of the immigrants from the reference group. At the other extreme, descendants of the immigrants from Yugoslavia are 23.8 percentage points more likely to agree with this claim than the reference country descendants. We match the coefficient on the Yugoslavia dummy to all five countries in the sample that by 2005 former Yugoslavia had broken into (i.e., Bosnia, Croatia, Macedonia, Slovenia, and Yugoslavia, comprised of Serbia and Montenegro; we later report on the strengthening effect on our estimates when removing Yugoslavia from the sample). We also assign the estimate on the Czechoslovakia dummy to both the Czech Republic and to Slovakia.

In general, we classify the bottom 50 percent of the countries in terms of gender bias relative to the reference group as low-gender bias countries. These countries are the Czech Republic, Germany, Greece, Ireland, Lithuania, Portugal, Russia, and Slovakia. Because the country-specific gender bias includes a measurement error, being an OLS regression estimate itself, in future tests, we pool these countries into the group of low-gender-bias countries. The rest of the countries we classify as the high-gender-bias countries. 
In the rest of the Table, we run the same model on the sample of male (columns (3)-(4)) and on the sample of female (columns (5)-(6)) respondents, in order to check whether cultural bias related to the role of women in society varies with the gender of the respondent. We find that in the case of male respondents, the effect of country of origin mirrors the full sample, while in the female sample, only in the case of Ireland and of Yugoslavia there is significant (negative and positive, respectively) gender bias. This suggests that males tend to be more extreme in their perception of the role of women in society than females; nevertheless, in neither case does the classification of countries of origin into low-gender-bias countries and high-gender-bias countries change substantially relative to the full sample, with the same split produced when taking male respondents' answers into account, and with only Poland and Portugal switching groups in the case of female respondents.

One caveat related to our approach is that even if we have a good proxy for inherited gender bias, the correlation between inherited values and contemporaneous economic outcomes can be interpreted as a causal relation only if the two variables are not codetermined by common factors. It is possible that changes in inherited trust and in credit access are driven by changes in institutions that disadvantage women. For example, if the legal system excludes women from the inheritance of property, female entrepreneurs will be less likely to have tangible collateral to pledge against bank credit, and this phenomenon may affect both gender bias and credit access. To address this issue, in robustness tests we calculate the gender bias from the earliest possible sub-sample of immigrants to the US. This does not change the ranking of countries in terms of gender bias, and hence the main results of the paper.

\subsection{Empirical strategy}

In order to tease out the causal effect of culture on credit market outcomes, we evaluate the effect of gender on credit market outcomes accounting for gender bias. For simplicity of illustration assume that countries can be divided into those with a high gender bias and those where society does not derive disutility from treating females as equal to males. We 
create a dummy variable equal to 1 if the US descendants of emigrants from the respective country have a higher gender bias than the US descendants of emigrants from the reference group, and to 0 if they have a lower gender bias. Then, we estimate the following equations:

$$
\text { Credit_access }_{\text {isc }}=\beta_{1} \text { Female }_{\text {isc }} \cdot \text { Bias }_{c}+\beta_{2} \text { Female }_{\text {isc }}+\beta_{3} X_{i s c}+\beta_{4} \Delta_{s c}+\varepsilon_{\text {isc }}
$$

and

$$
\text { Loan_term }_{\text {isct }}=\beta_{1} \text { Female }_{\text {isc }} \cdot \text { Bias }_{c}+\beta_{2} \text { Female }_{i s c t}+\beta_{3} X_{i s c}+\beta_{4} Y_{s c}+\beta_{5} \Delta_{\text {sct }}+\varepsilon_{\text {isct }}
$$

In model (1), we evaluate the effect of the gender of the owner of firm $i$ in sector $s$ in country $c$ on the probability of being rejected or discouraged in credit markets, as well as on the share of capital financed from bank versus non-bank sources, in high relative to low gender bias countries. ${ }^{11}$ The equation controls for firm $(X)$ characteristics, and it includes interactions of sector and country fixed effects $\left(\Delta_{s c}\right)$. Including firm characteristics is crucial since femaleowned firms may also be smaller, and so the effect of gender on credit we measure may be contaminated by the effect of size. The fixed effects are also crucial as they control for any market-sector unobservables that are common across all firms. For example, it is possible that there is disproportionate concentration of female entrepreneurs in industries which use more trade credit and less bank credit for technological reasons. While this "female-run agriculture vs. male-run manufacturing" story may be more applicable to developing economies than to the countries in our sample, we wish to fully account for such possibilities, and the comprehensive matrix of country and sector fixed effects does exactly that.

In model (2), we evaluate the effect of gender on the terms of granted loans (days to negotiate the loan, collateral, currency denomination, loan rate), in high relative to low gender

\footnotetext{
${ }^{11}$ In the case of our continuous variables for credit access and loan terms, we employ OLS. In the case of our dummy variables for credit access and loan terms, we employ a probit model, but the results are robust to using a logit model.
} 
bias countries. Although there is only one loan per firm, this regression has a panel component because loans were received at different points in time (between 1998 and 2005), which allows us to control for the time-varying component of the various country-level developments $(Y)$. The regressions also include different combinations of country, industry, and time fixed effects.

In the two equations, $\varepsilon_{i s c}$ and $\varepsilon_{i s c t}$, respectively, are i.i.d. error terms composed of a person-specific idiosyncratic shock and any unobservable sector-country (sector-country-year) fixed effects. We cluster the standard errors by country to allow for arbitrary within-country correlations in the errors.

In these specifications, $\beta_{2}$ measures the causal impact of being female on access to credit or on the terms of granted loans, respectively, and $\beta_{1}+\beta_{2}$ measures the effect of being female on credit market outcomes or on the terms of granted loans in countries with high gender bias.

\section{Results}

\subsection{Inherited cultural bias, gender, and credit market outcomes}

We first investigate the determinants of credit access. Table 4 reports the empirical estimates from Model (1). We start by zooming in on the sources of financing of working capital. We focus on bank credit and on trade credit. Prior work on the pecking order in corporate finance suggests that trade credit is the most expensive source of finance for the firm, and it is only used when no other source of external finance (such as bank credit) is accessible (e.g., Petersen and Rajan, 1994). We make two salient assumptions, i.e., that female firm owners have the same preferences over the pecking order and that they face the same probability of success when applying for trade credit. Then, female owners having relatively lower access to cheaper bank credit and having to rely relatively more on more expensive trade credit, especially in high-gender-bias countries, would be one manifestation consistent with taste-based discrimination. 
Column (1) of Panel A investigates the determinants of bank credit finance and column (2) the determinants of trade credit finance. Consistent with the prior literature we find that, all else equal, small firms and sole proprietorships are more credit constrained, potentially indicating a lower ability to tap alternative capital markets; firms that export part of their production are less constrained in terms of both types of finance, potentially signalling the willingness of banks and customers/suppliers to lend to firms with higher growth prospects; and audited firms are less credit constrained, implying gains from the reduction of informational opacity in terms of credit market access.

Turning to our primary variable of interest - the interaction term of "Gender bias" with "Female owner" — we find that a stronger gender bias in the country moderately decreases the share of working capital that is financed with bank credit in firms with female owners (column (1)). This effect is not statistically significant. At the same time, female firm owners appear to finance a smaller portion of their capital expenditures using bank loans, with this effect being significant across the board.

The estimate in column (2) implies that a strong gender bias sharply (and statistically significantly) increases the share financed with trade credit. Numerically, the estimated coefficient implies that if a firm with a female owner would move from Ireland to Spain, for example, trade credit financing would increase by 1.6 percentage points more than if the owner of the firms was a male. Given that the mean share of working capital financed with trade credit in the sample is only 6.4 percent, moving to a low-gender bias country would decrease reliance on informal credit by 25 percent.

In the next two columns, we investigate the determinants of being completely shut out from the credit markets, either because the firm was discouraged from applying (column (3)) or because it applied but its application was rejected (column (4)). We confirm the sign of the firm covariates; namely, small firms are both rejected and discouraged more often, while exporters and audited firms are less often credit constrained. Importantly, we find further evidence for a 
link between gender bias and credit access. Column (3) shows that female owners are more likely to be discouraged from applying for a loan in countries with high gender bias. Numerically, moving from Ireland to Spain increases discouragement by female owners by 6 percentage points more than male owners. Once again, this result is economically significant: Given that the mean probability of discouragement across all firms is 23 percent, a female entrepreneur in a low-gender bias country would be 26 percent less likely to be discouraged from applying for bank credit than in a high-gender-bias country, ceteris paribus. ${ }^{12}$

To get an idea of the aggregate effect, consider the following back-of-the-envelope calculation. In 2012, there were about $2.5 \mathrm{mln}$. SMEs in Spain. ${ }^{13}$ According to the BEEPS, 19 percent of these are female-owned, or 475,000 . Out of these, 61 percent have enough internal funds to finance their investment needs. Of the 39 percent female-owned firms with a strictly positive need of bank credit, 20 percent are discouraged from applying for a loan, which amounts to 37,000 firms in the aggregate. Our estimates imply that if Spain had as low gender bias as Ireland, an additional 2,200 female-owned firms would be applying for bank credit each year. Of course, this is a conservative calculation which disregards the fact that with lower gender bias, there could be many more female-owned firms to begin with.

Finally, the estimate of the coefficient on the interaction term in column (4) is not statistically significant (although it is economically relevant). This implies that the banking sector in high-gender-bias countries does not discriminate against female firm owners who actually apply for lines of credit. To take once again the example of Spain, our evidence suggests that if a female-owned SME with a positive need of bank credit were to apply for a line

\footnotetext{
${ }^{12}$ Female owners in strong gender bias countries may be discouraged from applying for a loan, not because they correctly anticipate rejection due to taste-based discrimination, but because they "internalize" the gender bias and feel less confident applying per se. As obtaining trade credit is also often a matter of requesting and negotiating it (yet we observe trade credit to increase) we do not think such a lack of confidence necessarily applies to the female owners in our sample.

${ }^{13}$ See the European Commission's “Enterprise and industry SBA Factsheet 2012: Spain”.
} 
of credit, it would face the same application approval rate (98 percent) as a male-owned SME. We conclude that in high-gender-bias countries, female entrepreneurs appear to be more likely to opt out of the loan application process, even though banks do not discriminate against females that end up applying for credit.

In Panel B, we account for the low number of degrees of freedom in our model by repeating the same exercise with bootstrapped standard errors. ${ }^{14}$ In particular, we sample with replacement in two stages: We first sample clusters with replacement, and then within cluster we sample from the individual observations. While the standard errors in this procedure are somewhat larger than the clustered standard errors, the two main effects (higher use of trade credit and higher probability of discouragement in high-gender-bias countries) survive this alternative test.

\subsection{Inherited cultural bias, gender, and loan terms}

Next we assess if the gender bias bias has an impact on the loan terms firms with female owners obtain, relative to firms owned by males. We thereby extend the framework in Alesina, Lotti, and Mistrulli (2013) who reject the hypothesis that banks do not price discriminate against females. However, we go beyond previous studies that focused on loan rates, by also looking at the effect of the firm owner's gender on the time it takes to negotiate the loan, on the loan's collateral, and on its currency denomination. Crucially, we compare these effects across high and low gender bias countries.

As reported in Table 5, we find that some of the variables which matter for credit access (as in Table 4) also have an impact on the terms of granted loans. In particular, small firms pay higher rates on bank loans (column (5)), but these loans are less likely to require collateral

\footnotetext{
${ }^{14}$ Ross, Turner, Godfrey, and Smith (2008) use a similar strategy to address the small sample problem in the case of discrimination in mortgage markets.
} 
(column (2)) and take a shorter time to negotiate (column (1)). On the contrary, exporters are charged lower rates by their bank (column (5)) and are more likely to have a loan in foreign currency (column (4)), potentially in order to reduce exchange rate risk vis-à-vis their export destination.

In terms of some of the time-varying country-level variables included in this regression, loan conditions are easier to negotiate in countries with better protection of creditors rights (column (1)), and banks charge on average higher rates in countries with higher restrictions on new business entry (column (5)).

Turning to the main variable of interest, and in sharp contrast to our earlier findings on credit access, the estimated coefficients on the interaction term of the "Gender bias" and "Female owner" are statistically insignificant in all but one case. For example, female-owned firms are no more likely to be charged higher rates on loans, both in high and in low gender bias countries (column (1)). We also find that in high-gender-bias countries, female- and maleowned firms do not differ in the time it takes to negotiate a loan (column (1)) or in collateralization conditions (columns (2) and (3)), either.

This collection of null results implies that in high-gender-bias countries there is no difference in the terms on loans between male- and female-owned firms that apply for and receive bank credit. At the same time, credit access by female-owned firms is statistically lower in high-gender-bias countries because female entrepreneurs are more likely to opt out of the formal credit granting process. Consequently, female-owned firms are more likely to resort to informal (and potentially more expensive) credit, such as trade credit.

\subsection{Robustness}

Our main model is very parsimonious, with inherited gender bias being the only countryspecific variable that is allowed to drive variations in credit outcomes across gender categories. To address this issue, we test a more saturated model in terms of country variation. We interact 
all country-specific variables introduced in Table 5 with the Female dummy. We next repeat our main tests after including all such interactions in the regression. ${ }^{15}$ In this version of the model, reported in Table 6, we fail to reject the hypothesis that gender bias does not induce femaleowned firms to rely more on trade credit (column (2)). However, we still find that gender bias results in female-owned firms being more likely to be discouraged from applying for bank credit (column (3)) and even rejected, once they do (column (4)).

Another issue is related to sample size. In particular, our measure of gender bias is calculated across a limited number of countries; we have only 17 countries in the BEEPS dataset. Furthermore, there are only 12 countries of origin in the GSS dataset which we use to calculate the proxy for gender bias used in the empirical tests. Part of this exercise relies on assigning one measure of gender bias to both the Czech Republic and to Slovakia, and one measure of gender bias to five countries from former Yugoslavia (Bosnia, Croatia, Macedonia, Serbia and Montenegro, and Slovenia). Such extrapolation may not be fully appropriate if these countries exhibited large cultural differences.

We address this issue in two different ways. First, we replace the dummy variable for gender bias that we have used so far with the continuous variable estimated in Table 3 . While the latter is clearly subject to measurement error, its advantage is that it does not separate in different groups medium-bias countries that are very close to each other in terms of numerical estimates (e.g., Germany and Greece). The estimates of these regressions are reported in Table 7, Panel A, and they imply that our main results are robust to this alternative specification. In Panel $B$, we address the same problem by simply dropping the three medium-bias countries (Germany, Greece, and Portugal). The estimates continue to suggest that in high-gender-bias countries, female firm owners are more likely to be discouraged from applying for bank credit

\footnotetext{
${ }^{15}$ See Appendix Table 3 for a version of this exercise where we include these interactions one at a time.
} 
and to resort to informal finance. ${ }^{16}$ Numerically, for example, the estimate reported in column (3) implies that females are statistically more likely to be discouraged from applying than men in countries where the continuous gender bias variable is higher than -0.02, a group which includes 12 countries rather than the 8 countries in the treatment group in our tests so far. Finally, in Panel $\mathrm{C}$ we use the ranking of countries produced by taking into account only female respondents' views on the role of women in society (see Table 5). In this test, higher gender bias does not result in higher discouragement by female-owned firms, but we still find that such firms are more likely to use trade credit than male-owned firms.

While the procedure in Table 7 goes some way in addressing the concern that our results may be contaminated by credit market experience in medium-bias countries, it only exacerbates the third problem which is related to the small size of our sample of countries. To that end, we next resort to the Global Entrepreneurship Monitor (GEM) to extract alternative measures of male and female entrepreneurial tendencies. The GEM collects survey data from current and potential entrepreneurs in 67 countries, ranging from Western Europe to SubSaharan Africa. While there are no questions related to access to finance, there are questions on entrepreneurial intentions summarized, by gender for each country. In particular, one of the questions in the survey asks non-entrepreneurs: "Do you intend to start a business in the next three years?" We hypothesize that if potential female entrepreneurs are less likely to start a business in the future-relative to male counterparts - in high-gender-bias countries, this can be interpreted as corroborative evidence to the one we have presented so far.

There are 28 countries which are present both in the GEM as a country of residence, and in the GSS as a country of origin. We repeat on this larger sample our test aimed at extracting

\footnotetext{
${ }^{16}$ In unreported regressions we exclude the 5 countries of former Yugoslavia that were given the same value for gender bias in the empirical procedure in Table 5; the magnitude of the effect of gender bias on discouragement increases by 50 percent and becomes significant at the 1 percent level.
} 
exogenous measures of inherited gender bias (See Section 3.A.). ${ }^{17}$ This allows us to extract measures of inherited gender bias for each of the 28 countries, as the coefficient on the country-of-origin dummy. Next, we calculate the variable Intention to start a business, $\Delta$ (Male - Female) as the difference in average entrepreneurial intentions for males and for females, for each country. This difference ranges from 0.02 in Sweden (where 12 percent of males intend to start a business in the next three years and 10 percent of females do) to 15 percent in Romania (where 35 percent of males intend to start a business in the next three years and 20 percent of females do). We then correlate this measure of relative entrepreneurial tendencies to our measure of inherited gender bias.

In Table 8, we report the estimates from this test. Column (1) suggests that gender bias has a statistically significant effect on the difference in entrepreneurial intentions between males and females. In column (2), we add the rest of the country-level variables employed in Table 5. The male-female gap in entrepreneurial tendencies widens with GDP growth and with good institutions for protection of creditors and for enforcement of contracts, and it is larger in countries with fewer entry barriers. Crucially, the male-female gap is still positively and statistically significantly (at the 10 percent level) correlated with our measure of gender bias derived from the GSS. ${ }^{18}$

\subsection{Interpretation of the results}

Our results so far indicate that credit access is far more problematic for female than for male firm owners in countries where the gender bias is strong. This is especially true in the case

\footnotetext{
${ }^{17}$ We now include the following countries, in addition to the ones included in the initial test reported in Table 5: Austria, Belgium, Denmark, Finland, France, Italy, Japan, Mexico, Netherlands, Norway, Sweden, Switzerland, and the UK. The Czech Republic and Lithuania are not included in the GEM.

${ }^{18}$ We calculate bootstrapped standard errors, to account for the small sample size.
} 
of discouragement from applying for bank credit. Loan rejection rates and loan terms, on the other hand, are not different between female- and male-owned firms.

Do these findings imply that there is taste-based discrimination against female entrepreneurs in countries with high gender bias? This question crucially depends on the nature of discouragement and on differences in ability across genders in those countries. Focusing on the first question, out of all the possible reasons for discouragement listed by firms, only one deals with beliefs about access ("the firm did not think their application would be approved"), while two deal with beliefs about credit terms that would be offered if the firm were to apply for a bank loan ("collateral requirements are too strict" and "interest rates are too high"). It is possible that in high-gender-bias countries, female entrepreneurs are less wealthy, in which case being discouraged by adverse credit terms would be a rational response to their inability to pledge collateral rather than a sign of discrimination.

To address this issue, we split the reasons for discouragement in the four categories for which there are sufficient number of answers (this procedure leads to the exclusion of discouragement due to the fact that "it is necessary to make informal payments to the bank"), and re-run Model (1). The estimates reported in Table 9 indicate that female entrepreneurs' discouragement is fully driven by the belief that their application would not be approved rather than by their perception of adverse credit terms. This finding strongly points in the direction of a belief-based "abstention" from partaking in the process to obtain credit. To the extent that this result may reflect a mechanism related to the fear of social stigma, it is reminiscent of microfinance studies which have found a tendency of female heads of households to underreport debt relative to males (e.g., Karlan and Zinman, 2010).

Turning to the question of differences in ability across genders, if male and female entrepreneurs are indeed of equal ability, then our results suggests that cultural attitudes lead female entrepreneurs to shy away from the formal credit granting process. At the loan 
application stage itself, however, the financial system does not seem to be discriminating, resulting in similar terms on granted loans. ${ }^{19}$

Alternatively, men and women could differ in other salient ways. For example, women tend to be more risk-averse (Powel and Ansic, 1997; Jianakoplos and Bernasek, 1998). More recent experimental evidence has suggested that gender-specific risk behaviour may be due to differences in opportunity sets rather than risk attitudes (Schubert, Brown, Gysler, and Brachniger, 1999), implying that women may be particularly more risk-averse in high-genderbias countries. In addition, women tend to dislike competition (Niederle and Vesterlund, 2007). These considerations might explain our result that female entrepreneurs are more likely to be discouraged from applying for a loan, especially in high-gender-bias countries. In addition, they also imply that in countries with a high gender bias, where women are discriminated against, only the most capable and competitive females start a business and therefore can survive to the loan application stage. In this case, the average female entrepreneur would be more skilled than the average male entrepreneur. If so, then equal loan conditions would actually point to taste-based discrimination as a potential explanation, this time at the loan approval stage.

However, female entrepreneurs could differ from male entrepreneurs in ways which would explain our results absent any taste-based discrimination. For example, if women are discriminated against, their inputs (such as education and training) might be of lower quality than those of men. Klumpp and Su (2013) argue that the belief that the human capital distribution exhibits less variation across females can be self-fulfilling, resulting in fewer "star" females and leading to a "glass ceiling" effect. Female firm owners might therefore face lower access to credit not because of direct discrimination at that stage, but because of differential

\footnotetext{
${ }^{19}$ Once access to credit through a non-discriminatory loan officer is possible, potentially because the loan officer herself is a female (Beck, Behr, and Madestam, 2012), similar loan terms suggest that female-owned firms are deemed to be similar to male-owned firms. However, we do not have information on the loan officer to investigate this possibility further.
} 
skill accumulation leading to lower expected growth or higher expected risk. Consistent with this idea, Cavaluzzo and Cavaluzzo (1998) and Blanchflower, Levine, and Zimmerman (2003) do not find significant evidence of gender based discrimination in the US credit market once proxies for firm risk are taken into account. The firm-level variables and interactions of sector and country dummies we have included in our tests so far only imperfectly control for firm growth or risk.

To investigate this point more formally, we now analyse the difference in firm growth across the dimensions of gender, gender bias, and access to credit. In Table 10, we run a version of our main tests where the independent variable is realised firm sales growth in the past three years. ${ }^{20}$ The results suggest that conditioning on firm-level observables and on country and industry fixed effects, there are no differences between male-owned and female owned in terms of sales growth (Column (1)), and that female-owned and male-owned firms exhibit similar growth rates in high-gender-bias countries, too (Column (2)). This goes somewhat against the idea of statistical discrimination in high-gender-bias countries whereby access to finance reflects the inferior skills of female entrepreneurs due to gender discrimination which starts early on in their lives. Crucially, the evidence also suggests that we cannot reject the null hypothesis that unconstrained male-owned firms and constrained maleowned firms grow at different rates (Column (3)), not even in high-gender-bias countries (Column (4)). This result suggests that there is no evidence to females having inferior skills to males in high-gender-bias countries (though recall our earlier discussion on the potentially confounding role played by latent unobservables in the selection and growth regressions).

Still, there are large differences across firms in the sample and across firms of different ownership types. For example, female-owned firms tend to be smaller, hence they may be less likely to need credit, and therefore will not be applying for a bank loan. Any such selection

\footnotetext{
${ }^{20}$ Our results are qualitatively unchanged when we repeat the tests for the logarithm of sales growth, in order to account for outliers.
} 
process can lead to a group of loans that are more similar and so potentially reduce gender differences within the sample. To address this issue, Table 11 we compare the mean characteristics of male- and of female-owned firms that applied and that did not apply for a loan. The table shows that differences in firms' characteristics between firms that applied and firms that did not apply for a bank loan are very similar for male-owned and for female-owned firms.

Of course, we have no way of fully eliminating alternative mechanisms related to unobservable differences between male and female entrepreneurs. One such mechanism can be related to spatial mismatch. For example, Rosenthal and Strange (2012) show that female entrepreneurs can be less networked than their male counterparts, and they may face greater domestic burdens, leading them to choose locations that are farther from agglomeration and are associated with shorter commuting distances. With such mechanism in place in gender bias countries where domestic burdens may be particularly high, female entrepreneurs may be less experienced in dealing with banks, and as a result be more reluctant to apply for credit. While we cannot entirely rule out this possibility, we think that this mechanism may not be as strong in most countries in our sample as these have fairly low birth rates, a communist past of gender equality when it comes to labor participation, and wide availability of child care facilities.

\section{Conclusion}

We analyse differential credit access and terms across 17 countries for female- versus male-owned firms using responses from 5,905 small family firms in the 2004/2005 wave of the Business Environment and Enterprise Performance Survey (BEEPS). We find that in high-genderbias countries, firms owned by females have lower access to bank credit than otherwise similar firms owned by males. This phenomenon is fully explained by the fact that in high-gender-bias countries, female entrepreneurs are more likely to opt out of the formal credit granting process, largely because they believe their loan application will be denied. In contrast, there are no statistical differences between female- and male-owned firms in loan rejection rates or in 
the terms on granted loans, such as rates or collateral required by the bank. We also find that female-owned firms do not underperform male-owned firms in terms of sales growth, even when not obtaining credit or when based in high-gender-bias countries, alleviating concerns that our results are driven by statistical discrimination.

Our findings suggest that culture may limit credit access of firms owned by females through a mechanism of self-selection out of the credit granting process. Once the credit application is made, similar approval rates and loan terms suggest female-owned firms are assessed to be identical to male-owned firms, and this assessment is correct because their credit worthiness also turns out to be statistically similar.

The contribution of our paper therefore consists in linking the severity of the inherited cultural gender bias as it exists across countries to one specific economic outcome (credit access). One potentially effective policy aimed at addressing the negative effect of culture on credit access is to stimulate banks to recruit and train female loan officers that may be viewed as less subject to a gender bias (Beck, Behr, and Guettler, 2013), which in turn could encourage female entrepreneurs to apply for loans or lines of credit. 


\section{Bibliography}

Aghion, P., Algan, Y., and P. Cahuc, 2011. Civil society and the state: The interplay between cooperation and minimum wage regulation. Journal of the European Economic Association 9, 3-42.

Aghion, P., Algan, Y., Cahuc, P., and A. Shleifer, 2010. Regulation and distrust. Quarterly Journal of Economics 125, 1015-1049.

Alesina, A., Lotti, F., and P. Mistrulli, 2013. Do women pay more for credit? Evidence from Italy. Journal of the European Economic Association 11, 45-66.

Algan, Y., and P. Cahuc, 2009. Civic virtue and labor market institutions. American Economic Journal: Macroeconomics 1, 111-145.

Algan, Y., and P. Cahuc, 2010. Inherited trust and growth. American Economic Review 100, 2060-2092.

Altonji, J., and R. Blank, 1999. Race and Gender in the Labor Market. In Ashenfelter, O. C. and D. Card (eds.), Handbook of Labour Economics, Elsevier Science Publishers 3, Chapter 48, 3143-3259.

Asiedu, E., Freeman, J., and A. Nti-Addae, 2012. Access to credit by small businesses: How relevant are race, ethnicity, and gender? American Economic Review 102, 532-537.

Asiedu, E., Kalonda-Kanyama, I., Ndikumana, L., and A. Nti-Addae, 2013. Access to credit by firms in Sub-Saharan Africa: How relevant is gender? American Economic Review, 103: 293297.

Aterido, R., Beck, T., and L. lacovone. 2013. Access to finance in Sub-Saharan Africa: Is there a gender gap? World Development 47, 102-120. 
Barr, A., and D. Serra, 2010. Corruption and culture: An experimental analysis. Journal of Public Economics 94, 862-869.

Bayer, P., Ferreira F., and S. L. Ross, 2014. Race, Ethnicity and High Cost Mortgage Lending. Department of Economics University of Connecticut, Storrs CT, Working Paper 36.

Bayard, K., Hellerstein, J., Neumark, D., and K. Troske, 2003. New evidence on sex segregation and sex differences in wages from matched employee-employer data. Journal of Labor Economics 21, 887-922.

Beck, T., Levine, R., and A. Levkov, 2010. Big bad banks? The winners and losers from bank deregulation in the United States. Journal of Finance 65, 1637-1667.

Beck, T., Behr, P. and A. Madestam, 2012. Sex and credit: Is there a gender bias in lending? European Banking Center Discussion Paper 17.

Beck, T., Behr, P., and A. Guettler, 2013. Gender and banking: Are women better loan officers? Review of Finance 17, 1279-1321.

Becker, G., 1957. The Economics of Discrimination. Chicago, IL: University of Chicago Press.

Bellucci, A., Borisov, A., and A. Zazzaro, 2010. Does gender matter in bank-firm relationships? Evidence from small business lending. Journal of Banking \& Finance 34, 29682984.

Berkovec, J. A., Canner, G. B., Gabriel, S. A., and T. H. Hannan, 1994. Race, redlining, and residential mortgage loan performance. Journal of Real Estate Finance and Economics 9, 263294.

Berkovec, J., Canner, G., Gabriel, S., and T. Hannan, 1996. Mortgage discrimination and FHA loan performance. Cityscape: A Journal of Policy Development and Research 2, 9-24. 
Berkovec, J., Canner, G., Gabriel, S., and T. Hannan, 1998. Discrimination, competition, and loan performance in fha mortgage lending. Review of Economics and Statistics 80, 241-250.

Bertrand, M., and S. Mullainathan, 2004. Are Emily and Greg more employable than Lakisha and Jamal? A field experiment on labor market discrimination. American Economic Review 94, 991-1013.

Blanchflower, D., Levine, P., and D. Zimmerman, 2003. Discrimination in the small business credit market. Review of Economics and Statistics 85, 930-943.

Brown, M., Jappelli, T., and M. Pagano, 2009. Information sharing and credit: Firm-level evidence from transition countries. Journal of Financial Intermediation 18, 151-172.

Brown, M., S. Ongena, A. Popov, and P. Yeşin, 2011. Who needs credit and who gets credit in Eastern Europe? Economic Policy 65, 93-130.

Carneiro, P., Heckman, J., and D. Masterov, 2005. Labor market discrimination and racial differences in pre-market factors. Journal of Law and Economics 48, 1-39.

Case, A., and C. Paxson, 2008. Stature and status: Height, ability, and labor market outcomes. Journal of Political Economy 116, 499-532.

Castilo, M., Petrie, R., Torero, M, and L. Vesterlund, 2013. Gender difference in bargaining outcomes: A field experiment on discrimination. Journal of Public Economics 99, 3548.

Cavalluzzo, K., and L. Cavalluzzo, 1998. Market structure and discrimination: The case of small businesses. Journal of Money, Credit, and Banking 30, 771-792.

Cavalluzzo, K., Cavalluzzo, L., and J. Wolken, 2002. Competition, small business financing, and discrimination: Evidence from a new survey. Journal of Business 75, 641-680. 
Cawley, J., 2004. The impact of obesity on wages. Journal of Human Resources 39, 451474.

Chakravarti, S., and M. Xiang, 2013. The international evidence on discouraged small businesses. Journal of Empirical Finance 20, 63-82.

Charles, K., and J. Guryan, 2008. Prejudice and the economics of discrimination. Journal of Political Economy 116, 773-809.

Duca J., and S. Rosenthal, 1993. Borrowing constraints, household debt, and racial discrimination in loan markets. Journal of Financial Intermediation 3, 77-103.

Garmaise, M., and T. Moskowitz, 2006. Bank mergers and crime: The real and social effects of credit market competition. Journal of Finance 61, 495-538.

Goldin, C., and C. Rouse, 2000. Orchestrating impartiality: The impact of "Blind" auditions on female musicians. American Economic Review 90, 715-741.

Guiso, L., Sapienza, P. and L. Zingales, 2004. The role of social capital in financial development. American Economic Review 94, 526-556.

Guiso, L., Sapienza, P. and L. Zingales, 2006. Does culture affect economic outcomes? Journal of Economic Perspectives 20, 23-48.

Guiso, L., Sapienza, P. and L. Zingales, 2009. Cultural biases in economic exchange. Quarterly Journal of Economics 124, 1095-1031.

Hamermesh, D., and J. Biddle, 1994. Beauty and the labor market. American Economic Review 84, 1174-1194.

Hertz, N., 2011. Women and banks: Are female customers facing discrimination? Institute for Public Policy Research, London. 
Jianakoplos, N., and A. Bernasek, 1998. Are women more risk averse? Economic Inquiry $36,620-630$.

Johnston, D., 2010. Physical appearance and wages: Do blondes have more fun? Economics Letters 108, 10-12.

Karlan, D., and J. Zinman, 2010. Expanding credit access: Using randomized supply decisions to estimate the impacts. Review of Financial Studies 23, 433-464.

Klumpp, T., and X. Su, 2013. Second-order statistical discrimination. Journal of Public Economics 97, 108-116.

Knack, S., and P. Keefer, 1997. Does social capital have an economic payoff? A crosscountry investigation. Quarterly Journal of Economics 112, 1251-1288.

Levine, R., and Y. Rubinstein, 2011. Racial discrimination and competition. CEP Discussion Paper 1069.

Mobius, M., and T. Rosenblat, 2006. Why beauty matters. American Economic Review 96, 222-235.

Mulligan, C., and Y. Rubinstein, 2008. Selection, investment, and women's relative wages over time. Quarterly Journal of Economics 123, 1061-1110.

Muravyev, A., Schäfer, D., and O. Talavera, 2012. Entrepreneurs' gender and financial constraints: Evidence from international data. Journal of Comparative Economics 37, 270-286.

Neal, D., and W. Johnson. 1996. The role of premarket factors in black-white wage differences. Journal of Political Economy 104, 869-895.

Niederle, M., and L. Vesterlund, 2007. Do women shy away from competition? Do men compete too much? Quarterly Journal of Economics 122, 1067-1101. 
Ongena, S., Popov, A., and G. Udell, 2013. 'When the cat's away the mice will play:' Does regulation at home affect bank risk taking abroad? Journal of Financial Economics 108, 727-750.

Paulson, A., and U. Osili, 2008. What can we learn about financial access from U.S. immigrants? The role of country of origin institutions and immigrant beliefs. World Bank Economic Review 22, 431-455.

Persico, N., Postlewaite, A., and D. Silverman, 2004. The effect of adolescent experience on labor market outcomes: The case of height. Journal of Political Economy 112, 1019-1053.

Petersen, M., and R. Rajan, 1994. The benefits of lending relationships: Evidence from small business data. Journal of Finance 49, 3-37.

Pistor, K., Raiser, G., and S. Gelfer, 2000. Law and finance in transition countries. Economics of Transition 8, 325-368.

Popov, A., and G. Udell, 2012. Cross-border banking, credit access, and the financial crisis. Journal of International Economics 87, 147-161.

Powell, M., and D. Ansic, 1997. Gender differences in risk behaviour in financial decisionmaking: An experimental analysis. Journal of Economic Psychology 18, 605-628.

Putnam, R., 2000. Bowling Alone: The Collapse and Revival of American Community. New York: Simon and Schuster.

Putnam, R., Leonardi, R., and R. Nanetti, 1993. Making Democracy Work: Civic Traditions in Modern Italy. Princeton, NJ: Princeton University Press.

Rodgers, W., and W. Spriggs, 1996. The effect of federal contractor status on racial differences in establishment-level employment shares: 1979-1992. American Economic Review 86, 290-293. 
Rosenbaum, P., and D. Rubin, 1983. The central role of the propensity score in observational studies for causal effects. Biometrika 70, 41-55.

Rosenthal, S., and W. Strange 2012. Female entrepreneurship, agglomeration, and a new spatial mismatch. Review of Economics and Statistics 94, 764-788.

Ross, S. L., 1996. Mortgage lending discrimination and racial differences in loan default. Journal of Housing Research 7, 117-126.

Ross, S. L., 1997. Mortgage lending discrimination and racial differences in loan default: A simulation approach. Journal of Housing Research 8, 277-297.

Ross, S. L., Galster, G., and J. Yinger, 1996. Rejoinder to Berkovec, Canner, Gabriel, and Hannan. Cityscape: A Journal of Policy Development and Research 2, 55-58.

Ross, S. L., and J. Yinger, 2002. The Color of Credit. Mortgage Discrimination, Research Methodology, and Fair-lending Enforcement. MIT Press, Cambridge MA.

Ross, S., Turner, M., Godfrey, E., and R. Smith, 2008. Mortgage lending in Chicago and Los Angeles: A paired testing study of the pre-application process. Journal of Urban Economics 63, 902-919.

Schubert, R., Brown, M., Gysler, M., and H. Brachniger, 1999. Financial decision making: Are women really more risk-averse? American Economic Review 89, 381-385.

Tabellini, G., 2008. Institutions and culture. Journal of the European Economic Association 6, 255-294.

White, H., 1980. A heteroskedasticity-consistent covariance matrix estimator and a direct test for heteroskedasticity. Econometrica 48, 817-838. 
Table 1. Credit access, by country

\begin{tabular}{lccccc}
\hline \multicolumn{1}{c}{ Country } & \# firms & $\begin{array}{c}\text { Share working } \\
\text { capital financed } \\
\text { with bank credit }\end{array}$ & $\begin{array}{c}\text { Share working } \\
\text { capital financed } \\
\text { with trade credit }\end{array}$ & $\begin{array}{c}\text { Firm discouraged } \\
\text { from applying } \\
\text { for a loan }\end{array}$ & $\begin{array}{c}\text { Loan } \\
\text { application } \\
\text { rejected }\end{array}$ \\
\hline Bosnia & 141 & 0.18 & 0.04 & 0.17 & 0.01 \\
Croatia & 141 & 0.15 & 0.06 & 0.10 & 0.02 \\
Czech Republic & 253 & 0.07 & 0.06 & 0.36 & 0.16 \\
Germany & 778 & 0.13 & 0.11 & 0.10 & 0.08 \\
Greece & 498 & 0.10 & 0.12 & 0.11 & 0.01 \\
Hungary & 462 & 0.12 & 0.05 & 0.25 & 0.03 \\
Ireland & 395 & 0.24 & 0.09 & 0.02 & 0.02 \\
Lithuania & 141 & 0.10 & 0.13 & 0.24 & 0.05 \\
Macedonia & 153 & 0.04 & 0.06 & 0.42 & 0.04 \\
Poland & 763 & 0.06 & 0.04 & 0.31 & 0.09 \\
Portugal & 370 & 0.08 & 0.04 & 0.25 & 0.03 \\
Romania & 393 & 0.12 & 0.06 & 0.42 & 0.12 \\
Russia & 434 & 0.04 & 0.07 & 0.15 & 0.08 \\
Slovakia & 142 & 0.06 & 0.02 & 0.08 & 0.03 \\
Slovenia & 132 & 0.15 & 0.03 & 0.14 & 0.01 \\
Spain & 501 & 0.12 & 0.00 & 0.39 & 0.02 \\
Yugoslavia & 208 & 0.08 & 0.05 & 0.06 & 0.03 \\
Total & 5,905 & 0.11 & 0.03 & 0.05 \\
\hline Note: This table & & 0.03 & 0.03 & \\
\hline
\end{tabular}

Note: This table presents statistics on firm credit access, by country. Share working capital financed with bank credit is the proportion of the firm's working capital that has been financed by borrowing from private commercial banks in the past 12 months. Share working capital financed with trade credit is the proportion of the firm's working capital that has been financed with trade credit from suppliers or customers in the past 12 months. Firm discouraged from applying for a loan is a dummy equal to 1 if the firm did not apply for a bank loan because it thought it felt discouraged by credit market conditions, and equal to 0 otherwise (all dummies will have these two values; so the "equal to 0 otherwise" will no longer be included below). Loan application rejected is a dummy equal to 1 if the firm applied for credit and had its loan application rejected. See Appendix for variable definitions and data sources. 
Table 2. Loan-level variables

\begin{tabular}{lccccr}
\hline \multicolumn{1}{c}{ Country } & $\begin{array}{c}\text { Days to } \\
\text { negotiate loan }\end{array}$ & $\begin{array}{c}\text { Loan not } \\
\text { collateralized }\end{array}$ & $\begin{array}{c}\text { Collateral as } \\
\text { \% of loan }\end{array}$ & $\begin{array}{c}\text { Loan in foreign } \\
\text { currency }\end{array}$ & $\begin{array}{c}\text { Annualized } \\
\text { loan rate }\end{array}$ \\
\hline Bosnia & 18.48 & 0.05 & 203.48 & 0.01 & 10.30 \\
Croatia & 27.02 & 0.25 & 160.36 & 0.29 & 8.13 \\
Czech Republic & 32.91 & 0.18 & 122.20 & 0.03 & 10.04 \\
Germany & 18.72 & 0.06 & 123.69 & 0.02 & 7.74 \\
Greece & 17.42 & 0.44 & 132.72 & 0.04 & 7.35 \\
Hungary & 22.53 & 0.06 & 168.04 & 0.21 & 13.22 \\
Ireland & 16.12 & 0.37 & 158.22 & 0.02 & 4.74 \\
Lithuania & 27.30 & 0.19 & 135.15 & 0.33 & 5.93 \\
Macedonia & 22.00 & 0.05 & 198.05 & 0.45 & 11.37 \\
Poland & 22.77 & 0.20 & 153.18 & 0.12 & 13.06 \\
Portugal & 10.99 & 0.41 & 120.12 & 0.00 & 7.02 \\
Romania & 21.21 & 0.06 & 153.12 & 0.38 & 17.94 \\
Russia & 19.80 & 0.11 & 148.91 & 0.13 & 18.07 \\
Slovakia & 35.67 & 0.23 & 144.31 & 0.02 & 8.07 \\
Slovenia & 14.22 & 0.44 & 157.24 & 0.22 & 6.48 \\
Spain & 8.22 & 0.28 & 134.79 & 0.01 & 6.51 \\
Yugoslavia & 22.40 & 0.07 & 193.36 & 0.17 & 13.66 \\
Total & 19.52 & 0.20 & 148.85 & 0.11 & 9.85 \\
\hline
\end{tabular}

Note: This table presents statistics on firm financing, by country. Days to negotiate loan is the number of days it took to negotiate the loan with the bank from the day of application. Loan not collateralized is a dummy equal to 1 if the financing of the loan did not require collateral. Collateral as \% of loan is the value of the collateral required as a percentage of the loan value. Loan in foreign currency is a dummy equal to 1 if the loan is denominated in foreign currency. Annualized loan rate is the loan's annual rate of interest. See Appendix for variable definitions and data sources. 
Table 3. Country of origin and inherited gender bias

\begin{tabular}{|c|c|c|c|c|c|c|}
\hline & \multicolumn{6}{|c|}{ Traditional gender roles } \\
\hline & \multicolumn{2}{|c|}{ Full sample } & \multicolumn{2}{|c|}{ Male respondents } & \multicolumn{2}{|c|}{ Female respondents } \\
\hline & Coefficient & Standard error & Coefficient & Standard error & Coefficient & Standard error \\
\hline & $(1)$ & $(2)$ & (3) & $(4)$ & $(5)$ & $(6)$ \\
\hline \multicolumn{7}{|c|}{ Demographic characteristics } \\
\hline Age & $0.003 * *$ & $(0.001)$ & 0.001 & $(0.002)$ & $0.003^{* *}$ & $(0.002)$ \\
\hline Age squared / 100 & $0.005^{* * *}$ & $(0.001)$ & $0.007 * * *$ & $(0.002)$ & $0.003^{*}$ & $(0.002)$ \\
\hline Education & $-0.033 * * *$ & $(0.001)$ & $-0.032 * * *$ & $(0.002)$ & $-0.034 * * *$ & $(0.002)$ \\
\hline Male & $0.110 * * *$ & $(0.007)$ & ------- & & -------- & \\
\hline Catholic & $0.145^{* * *}$ & $(0.014)$ & $0.159 * * *$ & $(0.019)$ & $0.122 * * *$ & $(0.021)$ \\
\hline Protestant & $0.169 * * *$ & $(0.012)$ & $0.183^{* * *}$ & $(0.016)$ & $0.146 * * *$ & $(0.018)$ \\
\hline Jewish & 0.025 & $(0.033)$ & $0.119 * * *$ & $(0.047)$ & $-0.074^{*}$ & $(0.042)$ \\
\hline Muslim & $0.215 * * *$ & $(0.045)$ & $0.244^{* * *}$ & $(0.054)$ & $0.156^{* *}$ & $(0.078)$ \\
\hline Other & $0.157^{* * *}$ & $(0.022)$ & $0.174 * * *$ & $(0.030)$ & $0.133^{* * *}$ & $(0.032)$ \\
\hline Employed & $-0.118 * * *$ & $(0.010)$ & -0.015 & $(0.023)$ & $-0.140 * * *$ & $(0.011)$ \\
\hline Unemployed & $-0.103 * * *$ & $(0.020)$ & 0.008 & $(0.034)$ & $-0.146 * * *$ & $(0.027)$ \\
\hline Retired & $-0.083 * * *$ & $(0.015)$ & 0.008 & $(0.030)$ & $-0.096 * * *$ & $(0.018)$ \\
\hline Income category & $-0.010 * * *$ & $(0.002)$ & $-0.015^{* * *}$ & $(0.003)$ & $-0.008 * * *$ & $(0.002)$ \\
\hline \multicolumn{7}{|l|}{ Country of origin } \\
\hline Czechoslovakia & -0.032 & $(0.035)$ & -0.022 & $(0.055)$ & -0.040 & $(0.046)$ \\
\hline Germany & -0.009 & $(0.010)$ & -0.010 & $(0.015)$ & -0.007 & $(0.014)$ \\
\hline Greece & 0.019 & $(0.059)$ & 0.033 & $(0.085)$ & 0.004 & $(0.081)$ \\
\hline Hungary & $0.131^{* *}$ & $(0.059)$ & $0.232 * * *$ & $(0.082)$ & 0.051 & $(0.079)$ \\
\hline Ireland & $-0.048 * * *$ & $(0.012)$ & $-0.049 * * *$ & (0.019) & $-0.048 * * *$ & $(0.015)$ \\
\hline Lithuania & -0.028 & $(0.080)$ & -0.034 & $(0.134)$ & -0.022 & $(0.098)$ \\
\hline Poland & $0.035^{*}$ & $(0.023)$ & $0.081 * *$ & $(0.036)$ & -0.013 & $(0.033)$ \\
\hline Portugal & -0.005 & $(0.067)$ & -0.071 & (0.102) & 0.053 & $(0.090)$ \\
\hline Romania & $0.122 * *$ & $(0.062)$ & $0.146^{*}$ & $(0.091)$ & 0.100 & $(0.082)$ \\
\hline Russia & $-0.049 *$ & $(0.028)$ & $-0.111^{*}$ & $(0.056)$ & 0.004 & $(0.053)$ \\
\hline Spain & $0.098 * * *$ & $(0.038)$ & $0.186 * * *$ & $(0.054)$ & 0.019 & $(0.051)$ \\
\hline Yugoslavia & $0.238 * *$ & $(0.095)$ & 0.195 & $(0.162)$ & $0.271^{* *}$ & $(0.120)$ \\
\hline Observations & \multicolumn{2}{|c|}{21,073} & \multicolumn{2}{|c|}{9,396} & \multicolumn{2}{|c|}{11,677} \\
\hline R-squared & \multicolumn{2}{|c|}{0.12} & \multicolumn{2}{|c|}{0.11} & \multicolumn{2}{|c|}{0.13} \\
\hline
\end{tabular}


Note: The dependent variable captures the views on the role of women in society inherited by US immigrants from the period 1935-2000. Traditional gender roles is a dummy variable based on answers to the question: "It is much better for everyone involved if the man is the achiever outside the home and the woman takes care of the home and family." The answers are given on a scale from 1 to 4, which correspond to "Strongly agree," "Agree," "Disagree," and "Strongly disagree." The dummy is equal to 1 if the respondent agrees or strongly agrees, and equal to 0 if the respondent disagrees or strongly disagrees. The reference group in religion is "Atheist". The reference group in employment is "Inactive". Data come from the General Social Survey. The regressions are based on male and female respondents (columns (1) - (2)), on male respondents (columns (3) - (4)), and on female respondents (columns (5) - (6)). Marginal effects from a Probit regression are reported in columns (1), (3), and (5). White (1980) robust standard errors, clustered at the country level, are reported in parentheses, where ${ }^{* * *}$ indicates significance at the $1 \%$ level, ${ }^{* *}$ at the $5 \%$ level, and ${ }^{*}$ at the $10 \%$ level. 
Table 4. Culture, gender, and credit access

Panel A. Non-bootstrapped standard errors

\begin{tabular}{|c|c|c|c|c|}
\hline & $\begin{array}{c}\text { Share working capital } \\
\text { financed with bank } \\
\text { credit }\end{array}$ & $\begin{array}{c}\text { Share working capital } \\
\text { financed with trade } \\
\text { credit }\end{array}$ & $\begin{array}{c}\text { Firm discouraged } \\
\text { from applying for a } \\
\text { loan }\end{array}$ & $\begin{array}{l}\text { Loan } \\
\text { application } \\
\text { rejected }\end{array}$ \\
\hline & $(1)$ & $(2)$ & (3) & (4) \\
\hline \multirow[t]{2}{*}{ Gender bias $\times$ Female owner } & -0.006 & $0.016 * *$ & $0.184 * *$ & 0.208 \\
\hline & $(0.011)$ & $(0.008)$ & $(0.083)$ & $(0.180)$ \\
\hline \multirow[t]{2}{*}{ Female owner } & $-0.027 * * *$ & 0.003 & -0.018 & 0.124 \\
\hline & $(0.006)$ & $(0.007)$ & $(0.055)$ & $(0.140)$ \\
\hline \multirow[t]{2}{*}{ Small firm } & $-0.046 * *$ & -0.006 & $0.614 * * *$ & $0.262 * * *$ \\
\hline & $(0.017)$ & $(0.010)$ & $(0.130)$ & $(0.080)$ \\
\hline \multirow[t]{2}{*}{ Large firm } & 0.026 & 0.017 & -0.109 & -0.260 \\
\hline & $(0.019)$ & $(0.020)$ & $(0.172)$ & $(0.325)$ \\
\hline \multirow[t]{2}{*}{ Originally private } & $0.029 * *$ & -0.006 & -0.120 & 0.036 \\
\hline & $(0.012)$ & $(0.012)$ & $(0.104)$ & $(0.217)$ \\
\hline \multirow[t]{2}{*}{ Exporter } & $0.032 * *$ & $0.019 * * *$ & $-0.345^{* * *}$ & $-0.302 *$ \\
\hline & $(0.013)$ & $(0.005)$ & $(0.094)$ & $(0.170)$ \\
\hline \multirow[t]{2}{*}{ Competition } & $0.025 * *$ & 0.005 & -0.074 & -0.129 \\
\hline & $(0.010)$ & $(0.006)$ & $(0.108)$ & $(0.083)$ \\
\hline \multirow[t]{2}{*}{ Subsidized } & $0.064 * * *$ & $0.016^{*}$ & $-0.754 * * *$ & $-0.550 * *$ \\
\hline & $(0.021)$ & $(0.019)$ & $(0.124)$ & $(0.240)$ \\
\hline \multirow[t]{2}{*}{ Audited } & $0.021 * * *$ & $-0.023^{*}$ & $-0.291 * * *$ & $-0.297 * *$ \\
\hline & $(0.007)$ & $(0.014)$ & $(0.110)$ & $(0.117)$ \\
\hline Country $\times$ Industry Fixed effects & Yes & Yes & Yes & Yes \\
\hline Observations & 5,307 & 5,307 & 2,817 & 1,837 \\
\hline R-squared & 0.10 & 0.09 & 0.20 & 0.13 \\
\hline \multicolumn{5}{|c|}{ Panel B. Bootstrapped standard errors } \\
\hline & $\begin{array}{c}\text { Share working capital } \\
\text { financed with bank } \\
\text { credit }\end{array}$ & $\begin{array}{c}\text { Share working capital } \\
\text { financed with trade } \\
\text { credit }\end{array}$ & $\begin{array}{c}\text { Firm discouraged } \\
\text { from applying for a } \\
\text { loan }\end{array}$ & $\begin{array}{l}\text { Loan } \\
\text { application } \\
\text { rejected }\end{array}$ \\
\hline & $\begin{array}{c}(1) \\
\end{array}$ & $(2)$ & (3) & (4) \\
\hline \multirow[t]{2}{*}{ Gender bias $\times$ Female owner } & -0.006 & $0.016 * *$ & $0.184^{*}$ & 0.208 \\
\hline & $(0.012)$ & $(0.009)$ & $(0.110)$ & $(0.315)$ \\
\hline \multirow[t]{2}{*}{ Female owner } & $-0.027 * * *$ & 0.003 & -0.018 & 0.124 \\
\hline & $(0.005)$ & $(0.004)$ & $(0.071)$ & $(0.287)$ \\
\hline Firm controls & Yes & Yes & Yes & Yes \\
\hline Country $\times$ Industry Fixed effects & Yes & Yes & Yes & Yes \\
\hline Observations & 5,307 & 5,307 & 2,817 & 1,837 \\
\hline R-squared & 0.08 & 0.05 & 0.17 & 0.11 \\
\hline
\end{tabular}

Note: This table presents OLS (columns (1) and (2)) and probit (columns (3) and (4)) regression results of indicators of credit market experience by firms on firm-level characteristics. All firms in the final sample are individually owned or family owned. The dependent variable is Share working capital financed with bank credit (column (1)), Share working capital financed with trade credit (column (2)), Firm discouraged from applying for a loan (column (3)), and Loan application rejected (column (4)). Gender bias is a country-level measure of inherited views on the role of women in society. It equals 1 if the country in which the firm is incorporated falls in the top half of the distribution of views on traditional gender roles by U.S. descendants of European immigrants, based on the regression in Table 5. Female owner is a dummy equal to 1 if the principal owner (or one of the principal owners) is 
a female. Small firm is a dummy equal to 1 if the firm has less than 20 employees. Large firm is a dummy equal to 1 if the firm has more than 100 employees. Originally private is a dummy equal to 1 if the firm was founded as a private company rather than privatized. Exporter is a dummy equal to 1 if the firm does not have access to foreign markets. Competition is a dummy equal to 1 if the firm faces fairly, very, or extremely strong competition. Subsidized is a dummy equal to 1 if the firm has received subsidies during the last 3 years from the central or local government. Audited is a dummy equal to 1 if the firm employs external auditing services. Omitted category for firm size is Medium firm. See Appendix for variable definitions and data sources. All regressions include fixed effects as specified. In Panel B, we estimate the model with bootstrapped standard errors. All other variables from Panel A are included in the regressions in Panel B (coefficients are not reported for brevity). White (1980) robust standard errors, clustered at the country level (Panel A), and bootstrapped standard errors (Panel B) are reported in parentheses, where ${ }^{* * *}$ indicates significance at the $1 \%$ level, ${ }^{* *}$ at the $5 \%$ level, and * at the $10 \%$ level. 
Table 5. Culture, gender, and loan terms

\begin{tabular}{|c|c|c|c|c|c|}
\hline & $\begin{array}{l}\text { Log days to } \\
\text { negotiate } \\
\text { loan }\end{array}$ & $\begin{array}{c}\text { Loan not } \\
\text { collateralized }\end{array}$ & $\begin{array}{c}\text { Log } \\
\text { collateral as } \\
\% \text { of loan }\end{array}$ & $\begin{array}{l}\text { Loan in } \\
\text { foreign } \\
\text { currency }\end{array}$ & $\begin{array}{c}\text { Annualized } \\
\text { loan rate }\end{array}$ \\
\hline & $(1)$ & $(2)$ & (3) & (4) & (5) \\
\hline Gender bias $\times$ Female owner & $\begin{array}{l}0.041 \\
(0.091)\end{array}$ & $\begin{array}{l}-0.101 \\
(0.157)\end{array}$ & $\begin{array}{l}-0.057 \\
(0.040)\end{array}$ & $\begin{array}{l}0.388^{*} \\
(0.220)\end{array}$ & $\begin{array}{l}-0.185 \\
(0.259)\end{array}$ \\
\hline Female owner & $\begin{array}{l}-0.124^{*} \\
(0.068)\end{array}$ & $\begin{array}{l}0.080 \\
(0.067)\end{array}$ & $\begin{array}{l}0.006 \\
(0.019)\end{array}$ & $\begin{array}{l}-0.398^{*} \\
(0.206)\end{array}$ & $\begin{array}{l}-0.063 \\
(0.172)\end{array}$ \\
\hline Small firm & $\begin{array}{l}-0.238^{* * *} \\
(0.071)\end{array}$ & $\begin{array}{l}0.248^{* *} \\
(0.115)\end{array}$ & $\begin{array}{l}0.021 \\
(0.032)\end{array}$ & $\begin{array}{l}-0.014 \\
(0.119)\end{array}$ & $\begin{array}{l}0.691^{* *} \\
(0.238)\end{array}$ \\
\hline Large firm & $\begin{array}{l}0.083 \\
(0.136)\end{array}$ & $\begin{array}{l}0.055 \\
(0.128)\end{array}$ & $\begin{array}{l}0.012 \\
(0.051)\end{array}$ & $\begin{array}{l}0.319^{*} \\
(0.178)\end{array}$ & $\begin{array}{l}-0.921^{*} \\
(0.491)\end{array}$ \\
\hline Originally private & $\begin{array}{l}0.099 \\
(0.092)\end{array}$ & $\begin{array}{l}-0.195^{*} \\
(0.116)\end{array}$ & $\begin{array}{l}0.043 \\
(0.039)\end{array}$ & $\begin{array}{l}0.118 \\
(0.160)\end{array}$ & $\begin{array}{l}0.124 \\
(0.385)\end{array}$ \\
\hline Exporter & $\begin{array}{l}-0.089^{*} \\
(0.046)\end{array}$ & $\begin{array}{l}-0.021 \\
(0.100)\end{array}$ & $\begin{array}{l}0.052 \\
(0.034)\end{array}$ & $\begin{array}{l}0.349 * * * \\
(0.101)\end{array}$ & $\begin{array}{l}-0.740^{* *} \\
(0.359)\end{array}$ \\
\hline Competition & $\begin{array}{l}-0.040 \\
(0.062)\end{array}$ & $\begin{array}{l}-0.194 \\
(0.153)\end{array}$ & $\begin{array}{l}0.033 \\
(0.022)\end{array}$ & $\begin{array}{l}0.016 \\
(0.070)\end{array}$ & $\begin{array}{l}0.344 \\
(0.342)\end{array}$ \\
\hline Subsidized & $\begin{array}{l}0.153 * * * \\
(0.048)\end{array}$ & $\begin{array}{l}-0.143 \\
(0.155)\end{array}$ & $\begin{array}{l}-0.037^{* *} \\
(0.016)\end{array}$ & $\begin{array}{l}-0.375^{* *} \\
(0.118)\end{array}$ & $\begin{array}{l}-0.179 \\
(0.444)\end{array}$ \\
\hline Audited & $\begin{array}{l}-0.015 \\
(0.057)\end{array}$ & $\begin{array}{l}0.130 \\
(0.135)\end{array}$ & $\begin{array}{l}-0.028 \\
(0.034)\end{array}$ & $\begin{array}{l}0.094 \\
(0.122)\end{array}$ & $\begin{array}{l}-0.009 \\
(0.310)\end{array}$ \\
\hline Private credit to GDP & $\begin{array}{l}-0.002 \\
(0.005)\end{array}$ & $\begin{array}{l}0.005 \\
(0.005)\end{array}$ & $\begin{array}{l}0.004^{* *} \\
(0.002)\end{array}$ & $\begin{array}{l}0.003 \\
(0.015)\end{array}$ & $\begin{array}{l}0.032 \\
(0.036)\end{array}$ \\
\hline Bank concentration & $\begin{array}{l}0.195 \\
(0.489)\end{array}$ & $\begin{array}{l}0.185 \\
(0.540)\end{array}$ & $\begin{array}{l}-0.077 \\
(0.139)\end{array}$ & $\begin{array}{l}1.230 \\
(1.025)\end{array}$ & $\begin{array}{l}0.392 \\
(1.929)\end{array}$ \\
\hline Information sharing & $\begin{array}{l}0.070^{*} \\
(0.036)\end{array}$ & $\begin{array}{l}0.034 \\
(0.032)\end{array}$ & $\begin{array}{l}0.025 \\
(0.018)\end{array}$ & $\begin{array}{l}0.065 \\
(0.093)\end{array}$ & $\begin{array}{l}-0.070 \\
(0.147)\end{array}$ \\
\hline Log GDP per capita & $\begin{array}{l}0.063 \\
(0.638)\end{array}$ & $\begin{array}{l}0.390 \\
(0.823)\end{array}$ & $\begin{array}{l}-0.359 \\
(0.279)\end{array}$ & $\begin{array}{l}-2.547 \\
(2.621)\end{array}$ & $\begin{array}{l}1.281 \\
(3.591)\end{array}$ \\
\hline GDP growth & $\begin{array}{l}0.025 \\
(0.025)\end{array}$ & $\begin{array}{l}-0.001 \\
(0.033)\end{array}$ & $\begin{array}{l}0.020^{* *} \\
(0.009)\end{array}$ & $\begin{array}{l}0.037 \\
(0.052)\end{array}$ & $\begin{array}{l}-0.030 \\
(0.093)\end{array}$ \\
\hline Creditors' rights & $\begin{array}{l}-0.194^{* *} \\
(0.084)\end{array}$ & $\begin{array}{l}0.068 \\
(0.102)\end{array}$ & $\begin{array}{l}-0.055 \\
(0.041)\end{array}$ & $\begin{array}{l}-0.194 \\
(0.338)\end{array}$ & $\begin{array}{l}0.410 \\
(0.712)\end{array}$ \\
\hline Population growth & $\begin{array}{l}0.184^{* * *} \\
(0.059)\end{array}$ & $\begin{array}{l}-0.016 \\
(0.169)\end{array}$ & $\begin{array}{l}-0.010 \\
(0.039)\end{array}$ & $\begin{array}{l}-0.296 \\
(0.275)\end{array}$ & $\begin{array}{l}-0.475 \\
(0.343)\end{array}$ \\
\hline Inflation & $\begin{array}{l}-0.007 \\
(0.006)\end{array}$ & $\begin{array}{l}0.006 \\
(0.012)\end{array}$ & $\begin{array}{l}0.004 \\
(0.003)\end{array}$ & $\begin{array}{l}-0.012 \\
(0.012)\end{array}$ & $\begin{array}{l}0.079 \\
(0.075)\end{array}$ \\
\hline Entry time & $\begin{array}{l}-0.018 \\
(0.022)\end{array}$ & $\begin{array}{l}0.057 \\
(0.102)\end{array}$ & $\begin{array}{l}0.020 * * \\
(0.008)\end{array}$ & $\begin{array}{l}-0.258 \\
(0.306)\end{array}$ & $\begin{array}{l}0.169 * \\
(0.094)\end{array}$ \\
\hline Country $\times$ Industry Fixed effects & Yes & Yes & Yes & Yes & Yes \\
\hline Year Fixed effects & Yes & Yes & Yes & Yes & Yes \\
\hline Observations & 2,158 & 2,199 & 1,708 & 2,114 & 2,119 \\
\hline R-squared & 0.21 & 0.15 & 0.17 & 0.23 & 0.59 \\
\hline
\end{tabular}

Note: This table presents OLS (columns (1), (3), and (5)) and probit (columns (2) and (4)) regression results of loan terms on firm-level and country-level characteristics. All firms in the final sample are individually owned or family owned. The dependent variable is the logarithm of Days to negotiate loan (column (1)), Loan not collateralized (column (2)), the logarithm of Collateral as \% of loan (column (3)), Loan in foreign currency (column (4)), and Nominal interest rate (column (5)). Gender bias is a country-level measure of inherited views on the role of 
women in society. It equals 1 if the country in which the firm is incorporated falls in the top half of the distribution of views on traditional gender roles by U.S. descendants of European immigrants, based on the regression in Table 5. Female owner is a dummy equal to 1 if the principal owner (or one of the principal owners) is a female. Small firm is a dummy equal to 1 if the firm has less than 20 employees. Large firm is a dummy equal to 1 if the firm has more than 100 employees. Originally private is a dummy equal to 1 if the firm was founded as a private company rather than privatized. Exporter is a dummy equal to 1 if the firm does not have access to foreign markets. Competition is a dummy equal to 1 if the firm faces fairly, very, or extremely strong competition. Subsidized is a dummy equal to 1 if the firm has received subsidies during the last 3 years from the central or local government. Audited is a dummy equal to 1 if the firm employs external auditing services. Omitted category for firm size is Medium firm. Foreign bank share denotes the assets held by all foreign banks as a share of the assets of all commercial banks. Private credit to GDP denotes the ratio of private credit by deposit money banks and other financial institutions to GDP. Bank concentration denotes the assets held by the three largest banks as a share of the assets of all commercial banks. Information sharing denotes the maximum of an index for private credit bureaus and an index for public credit registers. Log GDP per capita denotes the natural logarithm of per capita GDP. GDP growth denotes annual growth in gross domestic product per capita, average over the past three years. Creditors' rights denotes the degree of protection of creditors' rights. Contract enforcement denotes the number of days it takes to enforce a legal contract. Inflation denotes annual inflation, averaged over the past three years. Entry time denotes the time in days necessary to register a new business. See Appendix for variable definitions and data sources. All regressions include fixed effects as specified. White (1980) robust standard errors, clustered at the country level, are reported in parentheses, where $* * *$ indicates significance at the $1 \%$ level, ** at the $5 \%$ level, and * at the $10 \%$ level. 
Table 6. Culture, gender, and credit access: Robust controls

\begin{tabular}{|c|c|c|c|c|}
\hline & $\begin{array}{c}\text { Share working capital } \\
\text { financed with bank } \\
\text { credit }\end{array}$ & $\begin{array}{c}\text { Share working capital } \\
\text { financed with trade } \\
\text { credit }\end{array}$ & $\begin{array}{c}\text { Firm discouraged } \\
\text { from applying for a } \\
\text { loan }\end{array}$ & $\begin{array}{l}\text { Loan } \\
\text { application } \\
\text { rejected }\end{array}$ \\
\hline & $(1)$ & $(2)$ & (3) & (4) \\
\hline \multirow[t]{2}{*}{ Gender bias $\times$ Female owner } & -0.014 & 0.014 & $0.243^{*}$ & $0.612^{* *}$ \\
\hline & $(0.015)$ & $(0.010)$ & $(0.143)$ & $(0.256)$ \\
\hline \multirow[t]{2}{*}{ Female owner } & 0.104 & -0.060 & -0.199 & 0.099 \\
\hline & $(0.130)$ & $(0.062)$ & $(0.509)$ & $(0.834)$ \\
\hline Firm controls & Yes & Yes & Yes & Yes \\
\hline Country controls $\times$ Female owner & Yes & Yes & Yes & Yes \\
\hline Country $\times$ Industry Fixed effects & Yes & Yes & Yes & Yes \\
\hline Observations & 5,109 & 5,109 & 2,682 & 1,812 \\
\hline R-squared & 0.11 & 0.09 & 0.20 & 0.14 \\
\hline
\end{tabular}

Note: This table presents OLS (columns (1) and (2)) and probit (columns (3) and (4)) regression results of indicators of credit market experience by firms on firm-level characteristics. All firms in the final sample are individually owned or family owned. The dependent variable is Share working capital financed with bank credit (column (1)), Share working capital financed with trade credit (column (2)), Firm discouraged from applying for a loan (column (3)), and Loan application rejected (column (4)). Gender bias is a country-level measure of inherited views on the role of women in society. It equals 1 if the country in which the firm is incorporated falls in the top half of the distribution of views on traditional gender roles by U.S. descendants of European immigrants, based on the regression in Table 5 . Female owner is a dummy equal to 1 if the principal owner (or one of the principal owners) is a female. All other variables from Table 4 are included in the regressions (coefficients are not reported for brevity). Interactions of all country-specific variables from Table 5 with Female owner are included in the regressions (coefficients are not reported for brevity). See Appendix for variable definitions and data sources. All regressions include fixed effects as specified. White (1980) robust standard errors, clustered at the country level, are reported in parentheses, where *** indicates significance at the $1 \%$ level, ${ }^{* *}$ at the $5 \%$ level, and $*$ at the $10 \%$ level. 
Table 7. Culture, gender, and credit access: Robust measures of gender bias

Panel A. Continuous measure of gender bias

\begin{tabular}{|c|c|c|c|c|}
\hline & $\begin{array}{c}\text { Share working capital } \\
\text { financed with bank } \\
\text { credit }\end{array}$ & $\begin{array}{c}\text { Share working capital } \\
\text { financed with trade } \\
\text { credit }\end{array}$ & $\begin{array}{l}\text { Firm discouraged } \\
\text { from applying for a } \\
\text { loan }\end{array}$ & $\begin{array}{l}\text { Loan } \\
\text { application } \\
\text { rejected }\end{array}$ \\
\hline & $(1)$ & $(2)$ & (3) & $(4)$ \\
\hline \multirow[t]{2}{*}{ Gender bias $\times$ Female owner } & -0.048 & $0.108 * *$ & $0.761^{*}$ & 1.914 \\
\hline & $(0.085)$ & $(0.055)$ & $(0.406)$ & $(1.587)$ \\
\hline \multirow[t]{2}{*}{ Female owner } & $-0.027 * * *$ & 0.004 & 0.015 & 0.120 \\
\hline & $(0.005)$ & $(0.007)$ & $(0.058)$ & $(0.143)$ \\
\hline Firm controls & Yes & Yes & Yes & Yes \\
\hline Country $\times$ Industry Fixed effects & Yes & Yes & Yes & Yes \\
\hline Observations & 5,307 & 5,307 & 2,817 & 1,837 \\
\hline R-squared & 0.10 & 0.09 & 0.20 & 0.13 \\
\hline \multicolumn{5}{|c|}{ Panel B. Excluding medium-bias countries } \\
\hline & $\begin{array}{c}\text { Share working capital } \\
\text { financed with bank } \\
\text { credit }\end{array}$ & $\begin{array}{c}\text { Share working capital } \\
\text { financed with trade } \\
\text { credit }\end{array}$ & $\begin{array}{c}\text { Firm discouraged } \\
\text { from applying for a } \\
\text { loan }\end{array}$ & $\begin{array}{l}\text { Loan } \\
\text { application } \\
\text { rejected }\end{array}$ \\
\hline & $\begin{array}{c}(1) \\
\end{array}$ & $(2)$ & (3) & $(4)$ \\
\hline \multirow[t]{2}{*}{ Gender bias $\times$ Female owner } & -0.003 & $0.017^{*}$ & $0.187 * *$ & 0.213 \\
\hline & $(0.011)$ & $(0.010)$ & $(0.082)$ & $(0.226)$ \\
\hline \multirow[t]{2}{*}{ Female owner } & $-0.030 * * *$ & 0.003 & -0.025 & 0.125 \\
\hline & $(0.005)$ & $(0.009)$ & $(0.048)$ & $(0.197)$ \\
\hline Firm controls & Yes & Yes & Yes & Yes \\
\hline Country $\times$ Industry Fixed effects & Yes & Yes & Yes & Yes \\
\hline Observations & 3,916 & 3,916 & 2,190 & 1,352 \\
\hline R-squared & 0.11 & 0.08 & 0.19 & 0.15 \\
\hline
\end{tabular}

Panel C. Female bias

\begin{tabular}{|c|c|c|c|c|}
\hline & $\begin{array}{c}\text { Share working capital } \\
\text { financed with bank } \\
\text { credit }\end{array}$ & $\begin{array}{c}\text { Share working capital } \\
\text { financed with trade } \\
\text { credit }\end{array}$ & $\begin{array}{c}\text { Firm discouraged } \\
\text { from applying for a } \\
\text { loan }\end{array}$ & $\begin{array}{l}\text { Loan } \\
\text { application } \\
\text { rejected }\end{array}$ \\
\hline & $\begin{array}{c}(1) \\
\end{array}$ & $(2)$ & (3) & (4) \\
\hline \multirow[t]{2}{*}{ Gender bias $\times$ Female owner } & -0.007 & $0.018 *$ & 0.119 & 0.160 \\
\hline & $(0.010)$ & $(0.010)$ & $(0.108)$ & $(0.225)$ \\
\hline \multirow[t]{2}{*}{ Female owner } & $-0.025 * * *$ & -0.002 & -0.020 & 0.104 \\
\hline & $(0.008)$ & (0.009) & $(0.090)$ & $(0.210)$ \\
\hline Firm controls & Yes & Yes & Yes & Yes \\
\hline Country $\times$ Industry Fixed effects & Yes & Yes & Yes & Yes \\
\hline Observations & 5,307 & 5,307 & 2,817 & 1,837 \\
\hline R-squared & 0.10 & 0.09 & 0.20 & 0.13 \\
\hline
\end{tabular}

Note: This table presents OLS (columns (1) and (2)) and probit (columns (3) and (4)) regression results of indicators of credit market experience by firms on firm-level characteristics. All firms in the final sample are individually owned or family owned. In Panel A, Gender bias denotes the continuous measure of gender bias. In Panel B, Germany, Greece, and Portugal are dropped from the tests. In Panel C, Gender bias is constructed from the answers of female respondents in the General Social Survey (see Table 5 for details). The dependent variable is Share working capital financed with bank credit (column (1)), Share working capital financed with trade credit 
(column (2)), Firm discouraged from applying for a loan (column (3)), and Loan application rejected (column (4)). Gender bias is a country-level measure of inherited views on the role of women in society. It equals 1 if the country in which the firm is incorporated falls in the top half of the distribution of views on traditional gender roles by U.S. descendants of European immigrants, based on the regression in Table 3. Female owner is a dummy equal to 1 if the principal owner (or one of the principal owners) is a female. All other variables from Table 4 are included in the regressions (coefficients are not reported for brevity). See Appendix for variable definitions and data sources. All regressions include fixed effects as specified. White (1980) robust standard errors, clustered at the country level, are reported in parentheses, where ${ }^{* * *}$ indicates significance at the $1 \%$ level, ${ }^{* *}$ at the $5 \%$ level, and ${ }^{*}$ at the $10 \%$ level. 
Table 8. Gender bias and entrepreneurship: GEM data

\begin{tabular}{|c|c|c|}
\hline & \multicolumn{2}{|c|}{ Intention to start a business, $\Delta$ (Male - Female) } \\
\hline & $(1)$ & $(2)$ \\
\hline \multirow[t]{2}{*}{ Gender bias } & $0.189 * *$ & $0.122 *$ \\
\hline & $(0.076)$ & $(0.068)$ \\
\hline \multirow[t]{2}{*}{ Private credit to GDP } & & -0.003 \\
\hline & & $(0.010)$ \\
\hline \multirow[t]{2}{*}{ Bank concentration } & & 0.019 \\
\hline & & $(0.024)$ \\
\hline \multirow[t]{2}{*}{ Information sharing } & & 0.002 \\
\hline & & $(0.005)$ \\
\hline \multirow[t]{2}{*}{ Log GDP per capita } & & -0.018 \\
\hline & & $(0.015)$ \\
\hline \multirow[t]{2}{*}{ GDP growth } & & $0.421 *$ \\
\hline & & $(0.232)$ \\
\hline \multirow[t]{2}{*}{ Creditors' rights } & & $0.010 * * *$ \\
\hline & & $(0.003)$ \\
\hline \multirow[t]{2}{*}{ Contract enforcement } & & $0.007 * *$ \\
\hline & & $(0.003)$ \\
\hline \multirow[t]{2}{*}{ Inflation } & & 0.002 \\
\hline & & $(0.002)$ \\
\hline \multirow[t]{2}{*}{ Entry time } & & $-0.108 * *$ \\
\hline & & $(0.046)$ \\
\hline Observations & 28 & 28 \\
\hline R-squared & 0.21 & 0.68 \\
\hline
\end{tabular}

Note: This table presents OLS regression results of loan terms on firm-level and country-level characteristics. All firms in the final sample are individually owned or family owned. The dependent variable is the difference in the share of male and female non-entrepreneurs who declared an intention to become entrepreneurs in the next three years, from the Global Entrepreneurship Monitor (GEM). Gender bias is a country-level measure of inherited views on the role of women in society. It equals 1 if the country in which the firm is incorporated falls in the top half of the distribution of views on traditional gender roles by U.S. descendants of European immigrants, based on the regression in Table 3, for all countries in both the GSS and the GEM. Private credit to GDP denotes the ratio of private credit by deposit money banks and other financial institutions to GDP. Bank concentration denotes the assets held by the three largest banks as a share of the assets of all commercial banks. Information sharing denotes the maximum of an index for private credit bureaus and an index for public credit registers. Log GDP per capita denotes the natural logarithm of per capita GDP. GDP growth denotes annual growth in gross domestic product per capita, average over the past three years. Creditors' rights denotes the degree of protection of creditors' rights. Contract enforcement denotes the number of days it takes to enforce a legal contract. Inflation denotes annual inflation, averaged over the past three years. Entry time denotes the time in days necessary to register a new business. See Appendix for variable definitions and data sources. All regressions include fixed effects as specified. Bootstrapped standard errors are reported in parentheses, where *** indicates significance at the $1 \%$ level, $* *$ at the $5 \%$ level, and * at the $10 \%$ level. 
Table 9. Culture, gender, and credit access: Disentangling the components of discouragement

\begin{tabular}{lcccc}
\hline & $\begin{array}{c}\text { Application } \\
\text { procedures too } \\
\text { burdensome }\end{array}$ & $\begin{array}{c}\text { Collateral } \\
\text { requirements } \\
\text { too strict }\end{array}$ & $\begin{array}{c}\text { Interest rates } \\
\text { too high }\end{array}$ & $\begin{array}{c}\text { Did not think } \\
\text { application would } \\
\text { be approved }\end{array}$ \\
\cline { 2 - 5 } Gender bias $\times$ Female owner & $(1)$ & $(2)$ & $(3)$ & $(5)$ \\
Female owner & 0.043 & 0.090 & 0.169 & $0.679 * *$ \\
Firm controls & $(0.208)$ & $(0.186)$ & $(0.186)$ & $(0.349)$ \\
Country $\times$ Industry Fixed effects & -0.066 & 0.140 & 0.037 & -0.182 \\
Observations & $(0.090)$ & $(0.124)$ & $(0.109)$ & $(0.302)$ \\
R-squared & Yes & Yes & Yes & Yes \\
\hline Tote: This table preses & Yes & Yes & Yes \\
\end{tabular}

Note: This table presents probit regression results of various reasons for firms' being discouraged from applying for a loan even though they need one. All firms in the final sample are individually owned or family owned. The dependent variable is Application procedures too burdensome (column (1)), Collateral requirements too strict (column (2)), Interest rates too high (column (3)), and Did not think application would be approved (column (4)). Gender bias is a country-level measure of inherited views on the role of women in society. It equals 1 if the country in which the firm is incorporated falls in the top half of the distribution of views on traditional gender roles by U.S. descendants of European immigrants, based on the regression in Table 3. Female owner is a dummy equal to 1 if the principal owner (or one of the principal owners) is a female. All other variables from Table 4 are included in the regressions (coefficients are not reported for brevity). See Appendix for variable definitions and data sources. All regressions include fixed effects as specified. White (1980) robust standard errors, clustered at the country level, are reported in parentheses, where $* * *$ indicates significance at the $1 \%$ level, $* *$ at the $5 \%$ level, and * at the $10 \%$ level. 
Table 10. Culture, gender, credit access, and firm performance

\begin{tabular}{lllll}
\hline & \multicolumn{4}{c}{ Sales growth } \\
\cline { 2 - 5 } & $(1)$ & $(2)$ & $(3)$ & $(4)$ \\
\hline & 0.629 & 1.459 & & \\
Female owner & $(0.742)$ & $(1.360)$ & & \\
Gender bias $\times$ Female owner & & -1.725 & & \\
& & $(1.356)$ & & -1.173 \\
Constrained female vs unconstrained male & & & $(1.999)$ & $(3.735)$ \\
& & & & -1.098 \\
Gender bias $\times$ & & & & $(4.493)$ \\
Constrained female vs unconstrained male & Yes & Yes & Yes & Yes \\
Firm controls & Yes & Yes & Yes & Yes \\
Country $\times$ Industry Fixed effects & 3,173 & 3,173 & 1,251 & 1,251 \\
Observations & 0.06 & 0.06 & 0.11 & 0.11 \\
R-squared & & & & \\
\hline
\end{tabular}

Note: This table presents OLS regression results of indicators of credit market experience by firms on firm-level characteristics. All firms in the final sample are individually owned or family owned. The dependent variable in all columns is Sales growth. Female owner is a dummy equal to 1 if the principal owner (or one of the principal owners) is a female. Gender bias is a country-level measure of inherited views on the role of women in society. It equals 1 if the country in which the firm is incorporated falls in the top half of the distribution of views on traditional gender roles by U.S. descendants of European immigrants, based on the regression in Table 5. Constrained female vs unconstrained male is a dummy variable equal to 1 if the principle owner (or one of the principal owners) is a female and does not have a bank loan because she was rejected or was discouraged from applying, and is equal to 0 if the principle owner (or one of the principal owners) is a male whose loan application was approved. All other variables from Table 4 are included in the regressions (coefficients are not reported for brevity). See Appendix for variable definitions and data sources. All regressions include fixed effects as specified. White (1980) robust standard errors, clustered at the country level, are reported in parentheses, where ${ }^{* * *}$ indicates significance at the $1 \%$ level, ${ }^{* *}$ at the $5 \%$ level, and ${ }^{*}$ at the $10 \%$ level. 
Table 11. Mean characteristics of firms by gender and loan application choice

(Female applicants - female non-applicants) (Male applicants - male non-applicants)

\begin{tabular}{ll} 
Small firm & -0.314 \\
& $(0.220)$ \\
Large firm & 0.236 \\
& $(0.419)$ \\
Originally private & -0.159 \\
& $(0.116)$ \\
Exporter & $0.253^{*}$ \\
& $(0.145)$ \\
Competition & $-0.235^{*}$ \\
& $(0.119)$ \\
Subsidized & 0.184 \\
& $(0.204)$ \\
Audited & 0.069 \\
& $(0.158)$ \\
Observations & 3,218 \\
\hline
\end{tabular}

Note: This table presents differences in mean characteristics between the populations of female firm-owners, male-firm owners, applicants, and non-applicants. Small firm is a dummy equal to 1 if the firm has less than 20 employees. Large firm is a dummy equal to 1 if the firm has more than 100 employees. Originally private is a dummy equal to 1 if the firm was founded as a private company rather than privatized. Exporter is a dummy equal to 1 if the firm does not have access to foreign markets. Competition is a dummy equal to 1 if the firm faces fairly, very, or extremely strong competition. Subsidized is a dummy equal to 1 if the firm has received subsidies during the last 3 years from the central or local government. Audited is a dummy equal to 1 if the firm employs external auditing services. Omitted category for firm size is Medium firm. See Appendix for variable definitions and data sources. ${ }^{* * *}$ indicates significance at the $1 \%$ level, ${ }^{* *}$ at the $5 \%$ level, and * at the $10 \%$ level. 


\begin{tabular}{|c|c|c|}
\hline Variable Name & Definition & Source \\
\hline \multicolumn{3}{|c|}{ Firm characteristics } \\
\hline Female & Dummy = 1 if the principal owner (or one of the principal owners) of the firm is a female. & BEEPS 2004/05 \\
\hline Small firm & Dummy = 1 if firm has less than 20 employees. & BEEPS 2004/05 \\
\hline Medium firm & Dummy = 1 if the firm has between 20 and 100 employees. & BEEPS 2004/05 \\
\hline Large firm & Dummy = 1 if firm has more than 100 employees. & BEEPS 2004/05 \\
\hline Originally private & Dummy = 1 if firm was founded as a private company rather than through privatization. & BEEPS 2004/05 \\
\hline Exporter & Dummy = 1 if the firm has access to foreign markets. & BEEPS 2004/05 \\
\hline Competition & Dummy = 1 if the firm faces fairly, very, or extremely strong competition. & BEEPS 2004/05 \\
\hline Subsidized & $\begin{array}{l}\text { Dummy = } 1 \text { if the firm has received subsidies during the last } 3 \text { years from the central or } \\
\text { local government. }\end{array}$ & BEEPS 2004/05 \\
\hline Sales growth & The percentage change in sales in the past three years. & BEEPS 2004/05 \\
\hline $\begin{array}{l}\text { Constrained female vs } \\
\text { unconstrained male }\end{array}$ & $\begin{array}{l}\text { Dummy = } 1 \text { if the principle owner (or one of the principal owners) is a female who does not } \\
\text { have a bank loan because she was rejected or was discouraged from applying, and = } 0 \text { if } \\
\text { the principle owner (or one of the principal owners) is a male whose loan application was } \\
\text { approved. }\end{array}$ & BEEPS 2004/05 \\
\hline \multicolumn{3}{|c|}{ Credit access } \\
\hline
\end{tabular}

Share working capital financed with bank credit

Share working capital financed with trade credit

Loan application rejected

Firm discouraged from applying for a loan
The proportion of the firm's working capital that has been financed by borrowing from private commercial banks in the past 12 months.

The proportion of the firm's working capital that has been financed with trade credit from suppliers or customers in the past 12 months.

Dummy $=1$ if the firm applied for credit and had its loan application rejected.

Dummy = 1 if a firm that declared positive demand for credit did not apply for a bank loan because it was discouraged by adverse credit market conditions. Self-reported reasons for discouragement include: (a) application procedures are too burdensome, (b) collateral
BEEPS 2004/05

BEEPS 2004/05

BEEPS 2004/05

BEEPS 2004/05 
Application procedures too

Collateral requirements too strict

Interest rates too high

Did not think application would be approved burdensome

requirements are too high, (c) interest rates are too high, (d) informal payments are necessary, or (e) the firm did not think their application would be approved.

Dummy = 1 if a firm that declared positive demand for credit was discouraged from applying for credit because application procedures are too burdensome.

Dummy = 1 if a firm that declared positive demand for credit was discouraged from applying for credit because collateral requirements are too strict.

Dummy = 1 if a firm that declared positive demand for credit was discouraged from applying for credit because interest rates are too high.

Dummy = 1 if a firm that declared positive demand for credit was discouraged from applying for credit because it did not think that its application would be approved.

Loan terms

Days to negotiate loan

Loan not collateralized

Collateral as $\%$ of loan

Loan in foreign currency

Annualized loan rate

The loan's annual rate of interest.

Dummy = 1 if the financing of the loan did not require collateral.

The value of the collateral required as a percentage of the loan value.
BEEPS 2004/05

BEEPS 2004/05

BEEPS 2004/05

BEEPS 2004/05

The number of days it took to negotiate the loan with the bank from the day of application.

BEEPS 2004/05

BEEPS 2004/05

BEEPS 2004/05

BEEPS 2004/05

BEEPS 2004/05

\section{Country variables}

Traditional gender roles

Gender bias

Private credit

WB FDSD

Bank concentration
Country-level measure of the inherited views on the role of women in society by U.S. descendants of European immigrants. The underlying question is: "It is much better for everyone involved if the man is the achiever outside the home and the woman takes care of the home and family." The answers are given on a scale from 1 to 4 , which corresponds to "Strongly agree," "Agree," "Disagree," and "Strongly disagree." The indicator is equal to 1 if the respondent agrees or strongly agrees, and to 0 if the respondent disagrees or strongly disagrees.

Dummy = 1 if the country in which the firm is incorporated falls in the top half of the distribution of views on traditional gender roles by U.S. descendants of European immigrants, based on the regression in Table 5.

The ratio of private credit by deposit money banks and other financial institutions to GDP.
The assets held by the three largest banks as a share of the assets of all commercial banks. 
Information sharing

GDP growth

Creditors' rights

Population growth

Inflation

Entry time

Intention to start a business, $\Delta$

(Male - Female)
The maximum of an index for private credit bureaus and an index for public credit registers.

Annual growth in gross domestic product per capita, average over the past three years.

Degree of protection of creditors' rights.

Percentage change in total population, average over 2000-2005

Annual inflation, average over the past three years.

Time in days necessary to register a new business.

The difference in the share of male and female non-entrepreneurs who declared an intention to become entrepreneurs in the next three years.
WB DBD

PWT 6.3

WB DBD

WBDI

EBRD TR

WB DBD

GEM

Note: The Table uses the following sources: Business Environment and Enterprise Performance Survey (BEEPS), 2005; General Social Survey (GSS); European Bank for Reconstruction and Development Transition Report (2000-2005 EBRD TR); World Bank Financial Development and Structure Database by Thorsten Beck, Asli Demirguc-Kunt, and Vojislav Maksimovic, 2010 (WB FDSD); Penn World Tables (PWT 6.3); World Bank Doing Business database (WB DBD); World Bank Development Indicators (WBDI); Global Entrepreneurship Monitor (GEM). 
Appendix Table 1. Firm-level explanatory variables

\begin{tabular}{|c|c|c|c|c|c|c|c|c|}
\hline Country & Female owner & Small firm & Large firm & Originally private & Exporter & Competition & Subsidized & Audited \\
\hline Bosnia & 0.26 & 0.67 & 0.04 & 0.83 & 0.32 & 0.62 & 0.01 & 0.45 \\
\hline Croatia & 0.20 & 0.82 & 0.06 & 0.80 & 0.30 & 0.51 & 0.15 & 0.35 \\
\hline Czech Republic & 0.22 & 0.87 & 0.03 & 0.92 & 0.22 & 0.45 & 0.06 & 0.27 \\
\hline Germany & 0.20 & 0.85 & 0.06 & 0.99 & 0.13 & 0.00 & 0.13 & 0.47 \\
\hline Greece & 0.25 & 0.83 & 0.06 & 0.99 & 0.17 & 0.00 & 0.09 & 0.46 \\
\hline Hungary & 0.40 & 0.81 & 0.02 & 0.88 & 0.31 & 0.65 & 0.15 & 0.70 \\
\hline Ireland & 0.41 & 0.86 & 0.03 & 0.99 & 0.29 & 0.58 & 0.08 & 0.94 \\
\hline Lithuania & 0.26 & 0.74 & 0.04 & 0.79 & 0.32 & 0.64 & 0.06 & 0.36 \\
\hline Macedonia & 0.18 & 0.82 & 0.06 & 0.84 & 0.27 & 0.65 & 0.02 & 0.24 \\
\hline Poland & 0.34 & 0.87 & 0.02 & 0.95 & 0.21 & 0.65 & 0.08 & 0.30 \\
\hline Portugal & 0.50 & 0.91 & 0.04 & 0.99 & 0.10 & 0.00 & 0.04 & 0.74 \\
\hline Romania & 0.28 & 0.72 & 0.04 & 0.85 & 0.20 & 0.41 & 0.05 & 0.35 \\
\hline Russia & 0.28 & 0.75 & 0.07 & 0.86 & 0.13 & 0.22 & 0.01 & 0.35 \\
\hline Slovakia & 0.18 & 0.80 & 0.03 & 0.93 & 0.27 & 0.82 & 0.06 & 0.43 \\
\hline Slovenia & 0.35 & 0.92 & 0.02 & 0.86 & 0.42 & 0.68 & 0.10 & 0.20 \\
\hline Spain & 0.19 & 0.88 & 0.06 & 0.97 & 0.14 & 0.00 & 0.03 & 0.27 \\
\hline Yugoslavia & 0.25 & 0.82 & 0.06 & 0.89 & 0.25 & 0.56 & 0.05 & 0.24 \\
\hline Total & 0.29 & 0.83 & 0.04 & 0.93 & 0.21 & 0.35 & 0.08 & 0.44 \\
\hline
\end{tabular}

Note: This table presents firm-level statistics, by country. All firms in the final sample are individually- or family-owned. Female owner is a dummy equal to 1 if the principal owner (or one of the principal owners) is a female. Small firm is a dummy equal to 1 if the firm has less than 20 employees. Large firm is a dummy equal to 1 if the firm has more than 100 employees. Originally private is a dummy equal to 1 if the firm was founded as a private company rather than through privatization of a previously state-owned one. Exporter is a dummy equal to 1 if the firm has access to foreign markets. Competition is a dummy equal to 1 if the firm faces "fairly", "very", or "extremely" strong competition. Subsidized is a dummy equal to 1 if the firm has received subsidies during the last 3 years from the central or local government. Audited is a dummy equal to 1 if the firm employs external auditing services. Omitted category for firm size is Medium firm. See Appendix for variable definitions and data sources. 
Appendix Table 2. Country-level explanatory variables

\begin{tabular}{|c|c|c|c|c|c|c|c|c|c|c|}
\hline & Gender bias & $\begin{array}{c}\text { Private credit } \\
\text { to GDP }\end{array}$ & $\begin{array}{c}\text { Bank } \\
\text { concentration }\end{array}$ & $\begin{array}{c}\text { Information } \\
\text { sharing }\end{array}$ & $\begin{array}{c}\text { Log GDP per } \\
\text { capita }\end{array}$ & GDP growth & $\begin{array}{c}\text { Creditors' } \\
\text { rights }\end{array}$ & $\begin{array}{c}\text { Contract } \\
\text { enforcement }\end{array}$ & Inflation & Entry time \\
\hline Bosnia & 0.202 & 16.38 & 0.53 & 0.74 & 8.46 & 1.17 & 3.29 & 6.83 & 2.82 & 63 \\
\hline Croatia & 0.202 & 50.73 & 0.63 & 0.00 & 9.36 & 3.06 & 4.18 & 5.61 & 3.77 & 22 \\
\hline Czech Republic & -0.028 & 32.00 & 0.60 & 1.92 & 9.85 & 1.78 & 7.00 & 6.63 & 2.59 & 17 \\
\hline Germany & -0.008 & 115.44 & 0.68 & 6.00 & 10.28 & 0.62 & 8.00 & 4.03 & 1.50 & 18 \\
\hline Greece & 0.018 & 59.16 & 0.93 & 4.00 & 10.06 & 4.58 & 3.00 & 8.19 & 3.23 & 38 \\
\hline Hungary & 0.111 & 40.34 & 0.65 & 4.04 & 9.65 & 1.98 & 7.00 & 3.35 & 5.23 & 16 \\
\hline Ireland & -0.041 & 125.52 & 0.56 & 5.00 & 10.51 & 4.40 & 8.00 & 5.15 & 2.90 & 13 \\
\hline Lithuania & -0.027 & 22.48 & 0.78 & 3.00 & 9.36 & 3.28 & 5.00 & 2.10 & 1.91 & 26 \\
\hline Macedonia & 0.202 & 19.39 & 0.79 & 2.05 & 8.76 & 0.93 & 7.00 & 5.21 & 1.51 & 15 \\
\hline Poland & 0.029 & 26.92 & 0.59 & 2.76 & 9.44 & 1.80 & 8.00 & 9.98 & 3.24 & 31 \\
\hline Portugal & -0.001 & 137.24 & 0.88 & 4.00 & 9.88 & -0.39 & 3.00 & 5.77 & 3.03 & 7 \\
\hline Romania & 0.109 & 13.04 & 0.64 & 3.88 & 8.96 & 3.02 & 7.00 & 5.37 & 17.36 & 9 \\
\hline Russia & -0.036 & 19.86 & 0.22 & 0.00 & 9.34 & 3.38 & 3.00 & 2.81 & 19.26 & 29 \\
\hline Slovakia & -0.028 & 33.35 & 0.83 & 2.81 & 9.61 & 1.85 & 9.00 & 6.02 & 4.91 & 27 \\
\hline Slovenia & 0.202 & 43.97 & 0.67 & 2.90 & 9.98 & 1.93 & 5.00 & 14.25 & 3.99 & 60 \\
\hline Spain & 0.088 & 108.62 & 0.87 & 5.00 & 10.22 & 3.12 & 6.00 & 5.15 & 3.10 & 47 \\
\hline Yugoslavia & 0.202 & 19.37 & ------ & 0.00 & 8.64 & 2.15 & 7.00 & 9.40 & 14.43 & 23 \\
\hline Total & 0.046 & 61.85 & 0.67 & 3.43 & 9.71 & 2.28 & 6.16 & 6.04 & 5.59 & 25 \\
\hline
\end{tabular}

Note: The table summarizes various country-level characteristics used in the empirical analysis. Gender bias is the estimate of the inherited views on the role of women in society by U.S. descendants of European immigrants (see Table 5 for details). Foreign bank share denotes the assets held by all foreign banks as a share of the assets of all commercial banks. Private credit to GDP denotes the ratio of private credit by deposit money banks and other financial institutions to GDP. Bank concentration denotes the assets held by the three largest banks as a share of the assets of all commercial banks. Information sharing denotes the maximum of an index for private credit bureaus and an index for public credit registers. Log GDP per capita denotes the natural logarithm of per capita GDP. GDP growth denotes annual growth in gross domestic product per capita, average over the past three years. Creditors' rights denotes the degree of protection of creditors' rights. Contract enforcement denotes the number of days it takes to enforce a legal contract. Inflation denotes annual inflation, averaged over the past three years. Entry time denotes the time in days necessary to register a new business. See Appendix for variable definitions and data sources. 
Appendix Table 3. Adding country controls one at a time

\begin{tabular}{|c|c|c|c|c|c|c|c|c|c|c|}
\hline & \multicolumn{10}{|c|}{ Firm discouraged from applying for a loan } \\
\hline & $(1)$ & $(2)$ & (3) & (4) & (5) & (6) & $(7)$ & (8) & (9) & $(10)$ \\
\hline Gender bias $\times$ Female owner & $\begin{array}{l}0.170 * * \\
(0.174)\end{array}$ & $\begin{array}{l}0.192 * * \\
(0.079)\end{array}$ & $\begin{array}{l}0.188^{*} \\
(0.100)\end{array}$ & $\begin{array}{l}0.178 * * \\
(0.077)\end{array}$ & $\begin{array}{l}0.209 * * * \\
(0.082)\end{array}$ & $\begin{array}{l}0.184 * * \\
(0.084)\end{array}$ & $\begin{array}{l}0.186 * * \\
(0.087)\end{array}$ & $\begin{array}{l}0.174 * * \\
(0.083)\end{array}$ & $\begin{array}{l}0.212^{* * *} \\
(0.079)\end{array}$ & $\begin{array}{l}0.190 * * \\
(0.094)\end{array}$ \\
\hline Female owner & $\begin{array}{l}-0.099 \\
(0.117)\end{array}$ & $\begin{array}{l}-0.044 \\
(0.065)\end{array}$ & $\begin{array}{l}-0.061 \\
(0.136)\end{array}$ & $\begin{array}{l}-0.115^{* *} \\
(0.057)\end{array}$ & $\begin{array}{l}-0.109 \\
(0.100)\end{array}$ & $\begin{array}{l}-0.032 \\
(0.103)\end{array}$ & $\begin{array}{l}-0.018 \\
(0.055)\end{array}$ & $\begin{array}{l}-0.176 \\
(0.134)\end{array}$ & $\begin{array}{l}0.040 \\
(0.059)\end{array}$ & $\begin{array}{l}-0.062 \\
(0.159)\end{array}$ \\
\hline Foreign bank share $\times$ Female owner & $\begin{array}{l}0.171 \\
(0.177)\end{array}$ & & & & & & & & & \\
\hline Private credit to GDP $\times$ Female owner & & $\begin{array}{l}0.050 \\
(0.137)\end{array}$ & & & & & & & & \\
\hline Bank concentration $\times$ Female owner & & & $\begin{array}{l}0.078 \\
(0.250)\end{array}$ & & & & & & & \\
\hline Information sharing $\times$ Female owner & & & & $\begin{array}{l}0.034 * \\
(0.020)\end{array}$ & & & & & & \\
\hline Log GDP per capita $\times$ Female owner & & & & & $\begin{array}{l}0.005 \\
(0.006)\end{array}$ & & & & & \\
\hline GDP growth $\times$ Female owner & & & & & & $\begin{array}{l}0.006 \\
(0.037)\end{array}$ & & & & \\
\hline Population growth $\times$ Female owner & & & & & & & $\begin{array}{l}0.011 \\
(0.055)\end{array}$ & & & \\
\hline Creditors' rights $\times$ Female owner & & & & & & & & $\begin{array}{l}0.026 \\
(0.022)\end{array}$ & & \\
\hline Inflation $\times$ Female owner & & & & & & & & & $\begin{array}{l}-0.009 * * \\
(0.004)\end{array}$ & \\
\hline Entry time $\times$ Female owner & & & & & & & & & & $\begin{array}{l}0.002 \\
(0.005)\end{array}$ \\
\hline Firm controls & Yes & Yes & Yes & Yes & Yes & Yes & Yes & Yes & Yes & Yes \\
\hline Country $\times$ Industry Fixed effects & Yes & Yes & Yes & Yes & Yes & Yes & Yes & Yes & Yes & Yes \\
\hline Observations & 2,817 & 2,817 & 2,817 & 2,817 & 2,817 & 2,817 & 2,817 & 2,817 & 2,817 & 2,817 \\
\hline R-squared & 0.20 & 0.20 & 0.20 & 0.20 & 0.20 & 0.20 & 0.20 & 0.20 & 0.20 & 0.20 \\
\hline
\end{tabular}

Note: The dependent variable is Firm discouraged from applying for a loan. Gender bias is a country-level measure of inherited views on the role of women in society. It equals 1 if the country in which the firm is incorporated falls in the top half of the distribution of views on traditional gender roles by U.S. descendants of European immigrants, based on the regression in Table 5. Female owner is a dummy equal to 1 if the principal owner (or one of the principal owners) is a female. Foreign bank share denotes the assets held by all foreign banks as a share of the assets of all commercial banks. Private credit to GDP denotes the ratio 
of private credit by deposit money banks and other financial institutions to GDP. Bank concentration denotes the assets held by the three largest banks as a share of the assets of all commercial banks. Information sharing denotes the maximum of an index for private credit bureaus and an index for public credit registers. Log GDP per capita denotes the natural logarithm of per capita GDP. GDP growth denotes annual growth in gross domestic product per capita, average over the past three years. Population growth denotes the average change in the country's population. Creditors' rights denotes the degree of protection of creditors' rights. Inflation denotes annual inflation, averaged over the past three years. Entry time denotes the time in days necessary to register a new business. All other variables from Table 6 are included in the regressions (coefficients are not reported for brevity). See Appendix for variable definitions and data sources. All regressions include fixed effects as specified. White (1980) robust standard errors, clustered at the country level, are reported in parentheses, where ${ }^{* * *}$ indicates significance at the $1 \%$ level, ${ }^{* *}$ at the $5 \%$ level, and ${ }^{*}$ at the $10 \%$ level. 